\title{
Late Stage Interseismic Strain Interval, Cascadia Subduction Zone Margin, USA and Canada
}

\author{
Kenneth M. Cruikshank, Curt D. Peterson \\ Department of Geology, Portland State University, Portland, OR, USA \\ Email: CruikshankK@pdx.edu, PetersonC@pdx.edu
}

How to cite this paper: Cruikshank, K.M. and Peterson, C.D. (2017) Late Stage Interseismic Strain Interval, Cascadia Subduction Zone Margin, USA and Canada. Open Journal of Earthquake Research, 6, $1-34$.

https://doi.org/10.4236/ojer.2017.61001

Received: December 20, 2016

Accepted: February 13, 2017

Published: February 16, 2017

Copyright ( 92017 by authors and Scientific Research Publishing Inc. This work is licensed under the Creative Commons Attribution International License (CC BY 4.0).

http://creativecommons.org/licenses/by/4.0/

\begin{abstract}
Modern horizontal strain (2006-2016) measured along 56 new and 108 previously published GPS station baselines are used to establish the length (800 $\mathrm{km})$ and width $(300-400 \mathrm{~km})$ of the central Cascadia convergent margin seismogenic structure. Across-margin (west-east) annual rates of shortening range from $10^{-9} \mathrm{a}^{-1}$ at the eastern (landward) limit of the central Cascadia seismogenic structure to $10^{-7} \mathrm{a}^{-1}$ along the western onshore portion of the interplate zone. Relatively high shortening strain rates $\left(10^{-8} \mathrm{a}^{-1}\right.$ to $\left.10^{-7} \mathrm{a}^{-1}\right)$ are also measured in western transects from the northern (Explorer plate) and southern (Gorda plate) segments of the convergent margin, demonstrating that the full length of the margin (1300 km length) is currently capable of sustaining and/or initiating a major great earthquake. Vertical GPS velocities are averaged over the last decade at 321 stations to map patterns of uplift (0 - 5 $\left.\mathrm{mm} \mathrm{yr}^{-1}\right)$ and subsidence $\left(0-9 \mathrm{~mm} \mathrm{yr}^{-1}\right)$ relative to the study area mean. Along-margin belts of relative uplift and subsidence, respectively, are approximately associated with Coast Ranges and the Cascade volcanic arc. However, the vertical velocity data are locally heterogeneous, demonstrating patchy "anomalies" within the larger along-margin belts. A large coastal subsidence anomaly occurs in southwest Washington where the modern shortterm trend is reversed from the long-term $(\sim 200 \mathrm{yr})$ tidal marsh record of coastal uplift since the last co-seismic subsidence event (AD1700). The modern vertical displacements represent a late stage of the current inter-seismic interval. If the horizontal strain is considered largely or fully elastic, extrapolating the modern strain rates over the last 100 years show the accumulated strains would be similar in magnitude to the observed co-seismic strains resulting from the Tōhoku, Japan, Mw 9.0 earthquake in 2011. We believe that the central Cascadia seismogenic structure has accumulated sufficient elastic strain energy, during the last 300 years, to yield a $\mathrm{Mw} 9.0$ earthquake from a rupture of at least one-half ( $400 \mathrm{~km})$ of its length.
\end{abstract}




\section{Keywords}

Convergent Margin, Cascadia, Strain, Strain-Energy, GPS

\section{Introduction}

In previous papers [1] [2] we used continuously operating Global Positioning Stations (GPS) to document horizontal strain in the central Cascadia margin in the Pacific Northwest of the United States (Figure 1). Over 100 station-station baseline length changes (30 to $50 \mathrm{~km}$ spacing between GPS stations) were determined along seven west-east transects, two north-south transects and in three localized areas to determine the variation in strain over the central Cascadia convergent margin (Figure 1). These results showed (1) that strain extended further inland from the deformation front than expected, and (2) that west-east strain values substantially exceeded north-south strain values. The principle strain directions were about NW-SW, and changed orientation as the orientation of the margin changed, to remain approximately perpendicular to the margin.

In this paper, we extend the existing GPS transects further inland from the offshore deformation belt and add several margin-normal transects in the north and south areas of the Cascadia margin (Figure 2). Transects are added to the north, across Vancouver Island, Canada, where we do not have oblique convergence, and to the south into Northern California where the tectonic regime changes from convergent to transform. In this paper, we present the use of GPS vertical velocity data [3] [4] to analyze the vertical displacement trends at 321 fixed GPS sites in the central Cascadia margin. These initial analyses, from about a decade of vertical velocity measurements, are used to discriminate between relative uplift and subsidence of the upper plate surface across and along the onshore part of the subduction zone margin.

The analyses presented in this article demonstrate that the modern convergent horizontal strain extends to as much as $400 \mathrm{~km}$ landward from the deformation front or buried trench in the central Cascadia margin (Figure 1). The modern convergent strain occurs on both sides of the volcanic arc (the Cascade Mountains).

We identify a broad area of modern strain accumulation in the Cascadia margin as a large seismogenic structure, though the area extends landward of the inter-plate interface, which probably reaches the Cascade volcanic arc [1]. In the seaward portion of the seismogenic structure, the opposing plate motions impart stress to the upper plate across the plate interfaces, but the elastic strain is thought to be stored throughout the full thickness of the upper-plate and across the full width of the structure, which extends east of the Cascade Range (Figure 1). The deformed upper-plate serves as a capacitor of stored elastic strain energy prior to an earthquake. It is not known if the strain accumulated throughout the entire landward width of the Cascadia seismogenic structure is released during 
megathrust rupture, but that proved to be the case in the Tōhoku, Japan, $M_{w} 9.0$ earthquake in 2011 [5].

The horizontal strain is not recorded in the geologic record but paleo-cyclic vertical displacements are recorded in Cascadia tidal marshes [1] [7] [8]. The modern vertical displacements measured via GPS in this study differ from those recorded during the $\sim 200$-year interval of tidal marsh emergence after the last co-seismic rupture [AD 1700, [9]]. These results bear directly on previously unexpected relations between paleo-inter-seismic interval durations and magnitudes of interseismic uplift [10] and paleo-tsunami runup [11] in the central Cascadia margin. The patterns of GPS vertical displacements along the coast of the central Cascadia margin appear to represent a late stage of strain/vertical

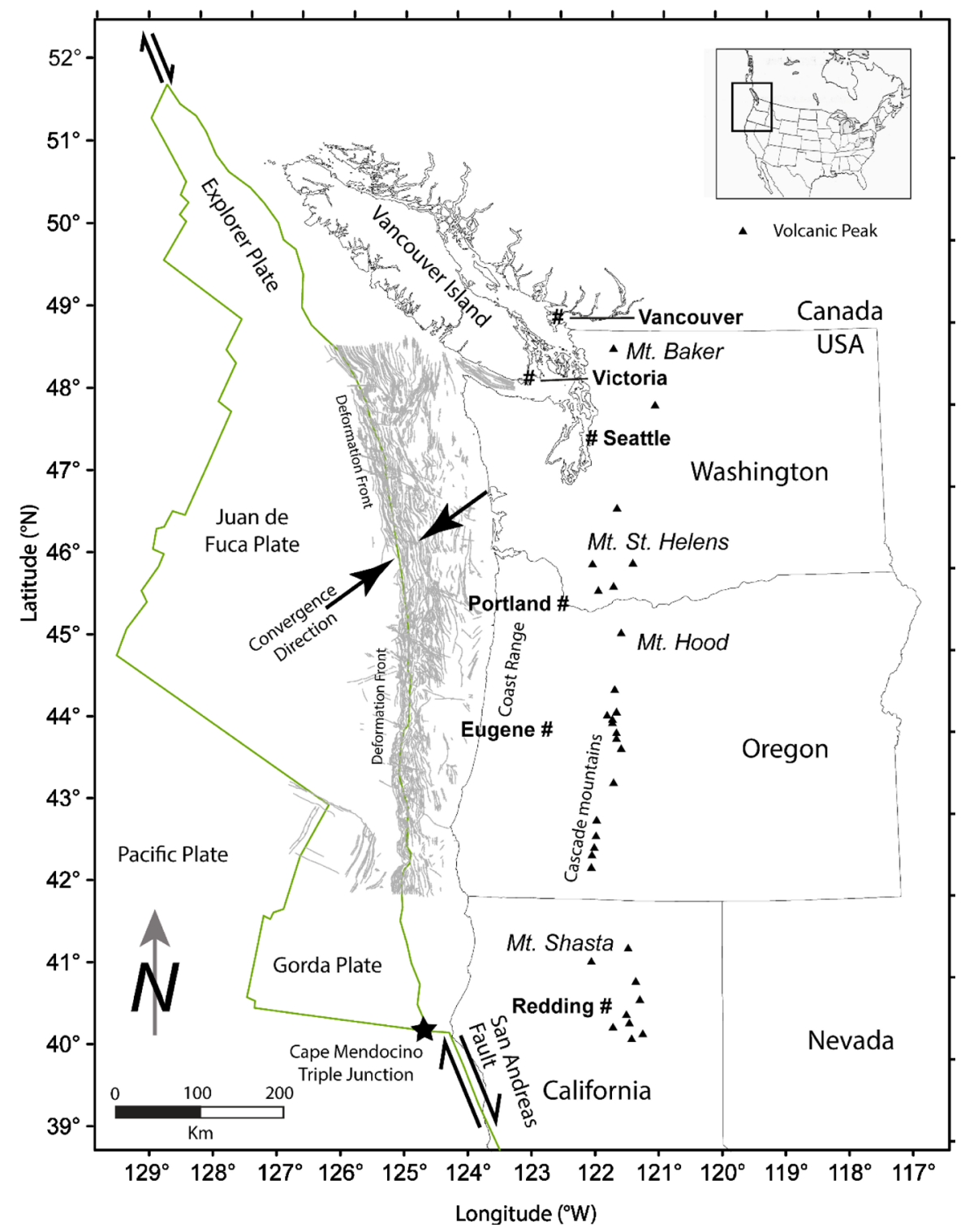

Figure 1. The Cascadia subduction zone, extending from the northern Explorer Plate segment to the central Juan de Fuca Plate segment, to the southern Gorda Plate segment. The subduction zone is bounded at transform triple junctions (opposing arrows) to the north and south. Offshore deformation belt by from [6]. 


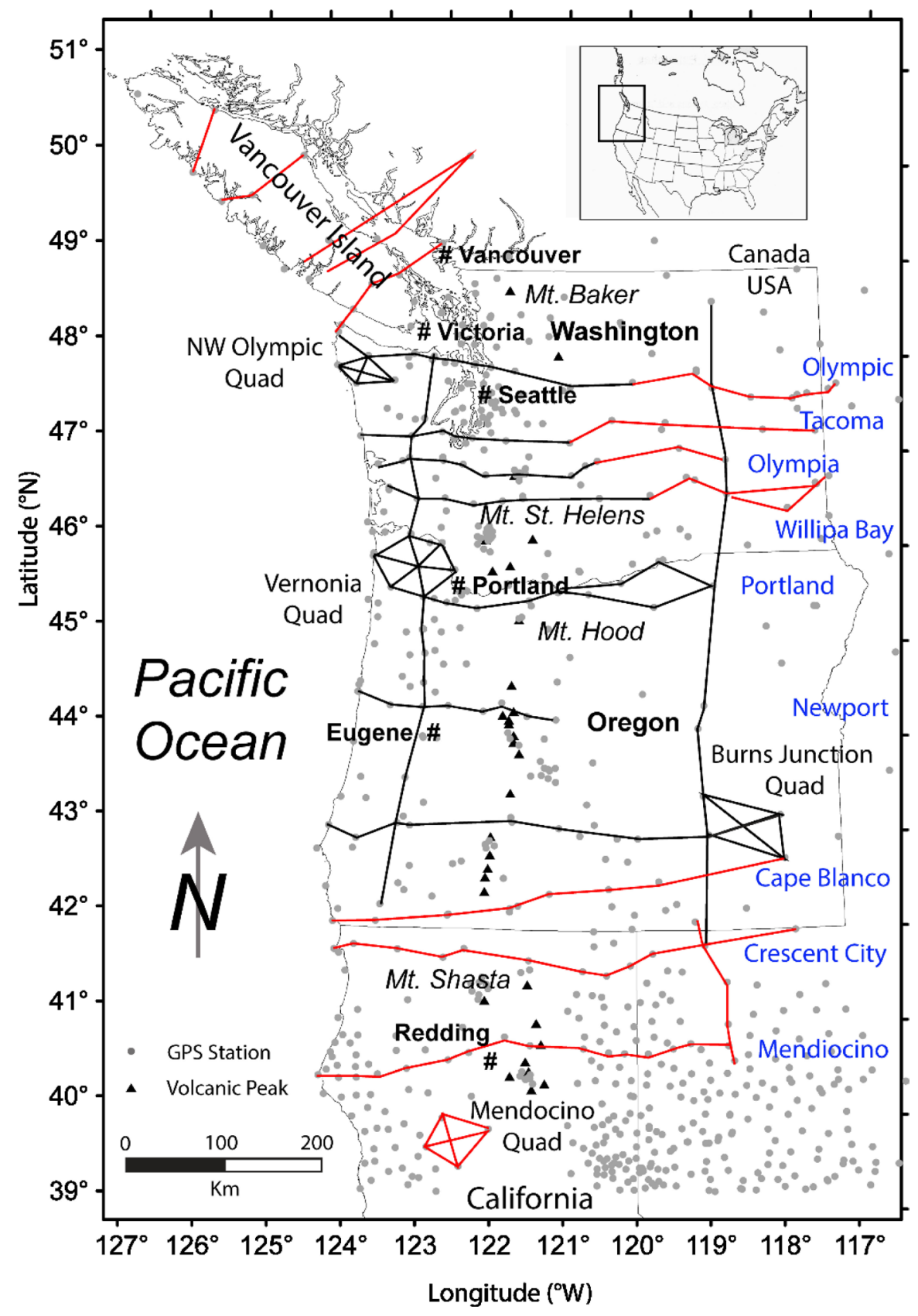

Figure 2. Regional map of GPS stations (dots) and horizontal strain baselines (between GPS sites) in across-margin transects (west-east orientations) and along-margin transects (north-south orientations) and previously published GPS baselines and quadrilaterals [1] are shown by black lines. New GPS baselines and one new quadrilateral, as presented in this article, are shown by red lines. The names of the E-W transects are in blue, and selected volcanoes are named.

displacement during the current interseismic strain interval, relative to prior tidal marsh uplift records after the last Cascadia rupture at AD1700 [e.g., [10]].

If all of the strain accumulated during the inter-seismic period (an average of 450 years between major ruptures for the Cascadia margin) is released during the earthquake event, as suggested using Reid's elastic rebound theory [12], then the observed modern strain rates are too large compared to the total strain re- 
leased in the Tōhoku earthquake in 2011 [e.g., [5]]. This suggests that over the seismic cycle a portion of the elastic strain must be converted to inelastic deformation or released in small amounts making that portion of the energy budget unavailable for release in an earthquake. We assume that most of the observed strain over the past decade to perhaps the century scale is elastic [1] and therefore could be released coseismically. In this paper, that amount of potential elastic strain energy, accumulated since the last rupture at AD1700, is estimated to predict a magnitude ( $\mathrm{Mw}$ 9.0) of a mega-thrust rupture of at least one-half (400 $\mathrm{km}$ ) of the central Cascadia margin.

In summary, in this paper we suggest that based on the current Cascadia strain rates compared with the strain released during the 2011 Tohoku earthquake that the Cascadia margin has been capable of generating a great earthquake since within 100 years from the last great earthquake (1700 AD), and that the current vertical deformation trends are similar to changes in the paleomarch subsidence records to just prior to previous great earthquakes.

\section{Background}

\subsection{Central Cascadia Margin}

Estimated oblique convergence $\left(030^{\circ} \mathrm{N}-050^{\circ} \mathrm{N}\right)$ of the central Cascadia margin at $\sim 4 \mathrm{~cm} \cdot \mathrm{yr}^{-1}$ (Figure 1) is associated with (1) episodic great subduction zone earthquakes ( $\mathrm{Mw} 8.5 \pm 0.5)$ with major-rupture recurrence intervals of $450 \pm$ 250 years [7] [13] [14] [15] [16], (2) large-scale paleo-liquefaction features at $100-170 \mathrm{~km}$ from the trench [17], and (3) nearfield paleo-tsunamis $(10 \pm 5 \mathrm{~m})$ adjusted shoreline run-up [11]. It has been 316 years since the last Cascadia rupture at $\sim \mathrm{AD} 1700$ [18]. The current strain conditions of the central Cascadia margin, as well as the northern and southern areas of the margin (total margin length $\sim 1300 \mathrm{~km}$ ) are of great interest to coastal cities and large inland metropolitan centers, located $80-300 \mathrm{~km}$ from the trench.

\subsection{Short-Term Horizontal Strains}

Previous horizontal strain analyses [1] [2] [19] consisted of seven west-east transects, two north-south transects, and three quadrilaterals in the central Cascadia margin. In the across-margin West-East transects many baselines showed shortening and others extension, with strain magnitudes of about $10^{-7} \mathrm{a}^{-1}$. North-South baselines in one transect (Figure 2) that extends along the Coast Ranges show shortening of about $10^{-8} a^{-1}$. Therefore, the dominantly shortening strain in the west-east direction (across-margin) was an order of magnitude greater than in the north-south direction (along-margin). The principle shortening direction was determined to be approximately NE-SW, thus oblique to both the N-S and E-W transects.

Onshore thrust faults in the southern Cascadia margin are orientated slightly oblique to the coast (NNW) and to the offshore buried trench, however, numerous Quaternary fold axes in the fold-and-thrust belt, mapped offshore of the central Cascadia margin (Figure 1), are shore-parallel and trench-parallel [20]. 
Furthermore, Quaternary fold axes mapped onshore in the southern part of the central Cascadia margin [2] are also orientated shore-parallel and trench parallel. The differences between directions of the margin-parallel Quaternary structures and the margin-oblique modern strain directions have not been reconciled, though their orientations might reflect across-margin gradients in plate strength or inherited structures. In any case, the principle shortening direction associated with modern horizontal strain is consistent with an assumed oblique direction of subduction (Figure 1) in the central Cascadia margin. Additional GPS base station transects (Figure 2) are utilized in this article to establish modern convergence strain directions in the northernmost and southernmost areas of the central Cascadia margin, and in transects that cross the Cascade volcanic arc, landward of previously published GPS baseline transects.

\subsection{Long-Term Vertical Displacements}

Long-term uplift rates of the central Coast Range at $100-150 \mathrm{~km}$ from the trench $\left(\sim 0.1-0.3 \mathrm{~mm} \cdot \mathrm{yr}^{-1}\right)$ are based on (1) uplifted shallow marine deposits (1000 - $1500 \mathrm{~m}$ elevation) since late Miocene time, and (2) uplifted marine terraces $(10-30 \mathrm{~m})$ since $\sim 83 \mathrm{ka}$ (MIS5a paleo-marine high-stand) [2]. The long-term uplift of the central Coast Range is assumed to represent interplate coupling and underplating in the shallow subduction zone $\left(5^{\circ}-15^{\circ}\right.$ landward dip) (Figure 3(a)). By comparison, the more landward forearc valleys (150 - 200 $\mathrm{km}$ landward of the trench) generally show little to no uplift ( $<300 \mathrm{~m}$ elevation) of pre-Neogene shallow marine deposits. Neogene volcanic deposits have obscured potential underlying marine rock records in the Cascade Range volcanic $\operatorname{arc}(200-300 \mathrm{~km}$ landward of the trench).

Cyclic vertical coastal displacements in the central Cascadia margin are established by interseismic uplift and co-seismic subsidence $(0.5-2.0 \mathrm{~m})$ records in late Holocene tidal marsh deposits (100 - $175 \mathrm{~km}$ from the trench) (Figure $3(b))$. The cyclic vertical displacements of tidal marshes are associated with (1) regional mega-folding on the landward side of the $1^{\text {st }}$ zero-isobase $(>100 \mathrm{~km}$ from the trench) and (2) local upper plate structures in the strongly coupled zone $(<100 \mathrm{~km}$ from the trench). Nearfield paleo-tsunami excitations in the Cascadia margin are attributed to coseismic ruptures of (1) the regional inter-plate mega-thrust and (2) local fault structures in the upper plate [21].

\subsection{Unexpected Relations between Inter-Seismic Interval and Uplift}

Two aspects of the interseismic uplift intervals are of special relevance to this article. They are evident in coastal marsh records of northern Oregon, where the regional uplift does not exceed the uppermost intertidal elevations, $+1.5 \mathrm{~m}$ mean tidal level (MTL) (Figure 4(a)). In Netarts Bay, Oregon the records of maximum uplift do not show a simple linear relation between duration of uplift and total net uplift (Figure 4(b)). A doubling of the inter-seismic time interval does not result in a doubling of the interseismic uplift. Most of the net uplift $(\sim 75 \mathrm{~cm})$ 
occurs in the first 200 - 300 years, followed by smaller amounts of uplift ( 25 $\mathrm{cm}$ ) during the next 300 - 500 years.

Some inter-seismic intervals of tidal marsh emergence along the northern Oregon coast, such as in the Siuslaw and Necanicum estuaries (Figure 4(c)), demonstrate apparent minor submergence prior to co-seismic subsidence [22] [23] [24]. Higher marsh settings gradually transition (contacts marked $g$ in Figure $4(c)$ ) to lower marsh settings just prior to co-seismic subsidence, which is recorded as a sharp transition to mud flat. The gradual submergence contacts show that the pre-earthquake submergence is aseismic and prolonged. The duration of such pre-seismic submergence events are not established by radiocarbon methods, but some pre-seismic submergence records do represent a significant length $(5 \%-15 \%)$ of the inter-seismic core log interval. The pre-seismic submergence events are not consistently evident between (1) different marsh localities and/or (2) different inter-seismic intervals within a locality. Their origins have not previously been addressed, but they have been informally recognized, starting with the first Cascadia Margin studies of marsh burial and tsunami inundation records in Alsea Bay, Oregon [25].

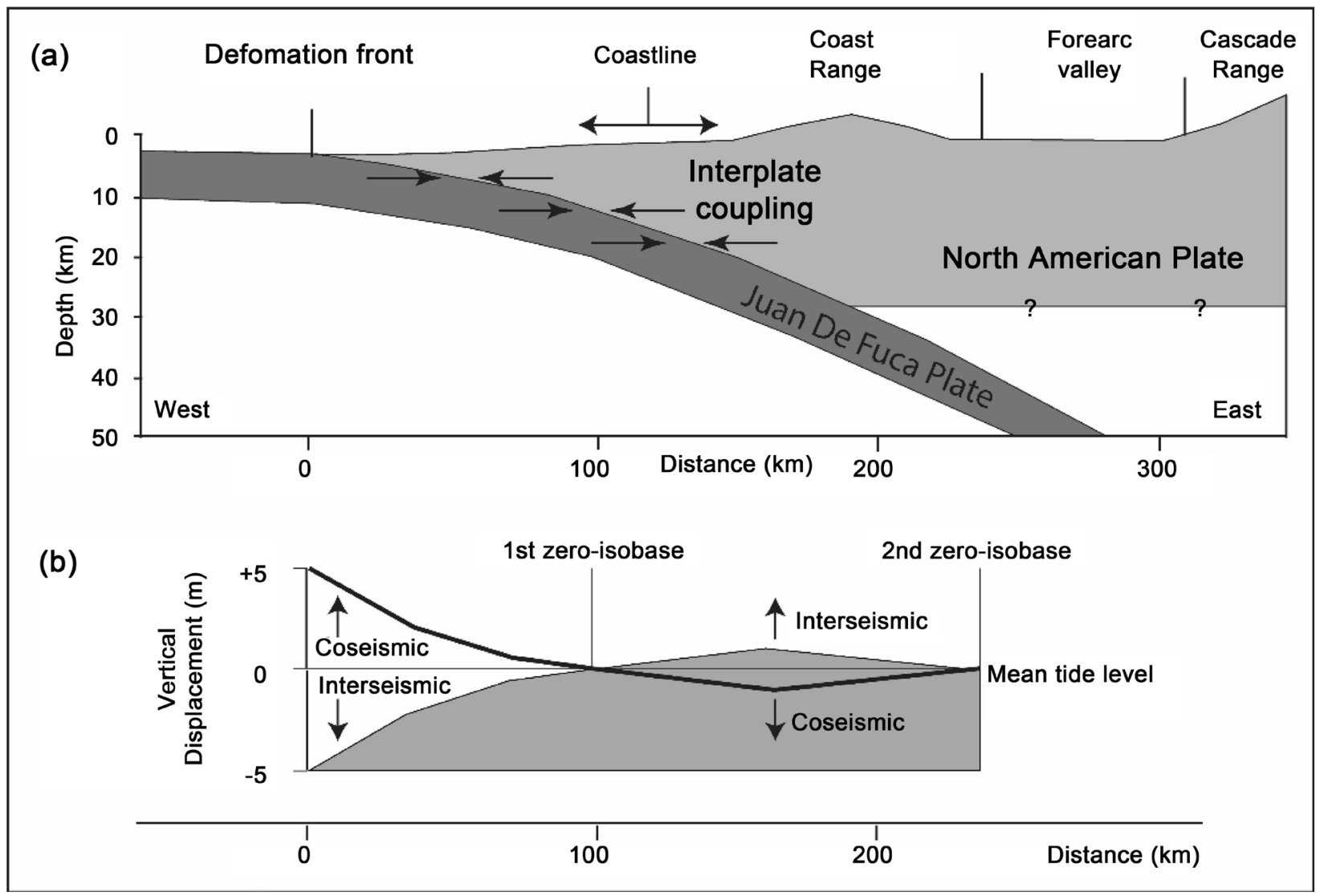

Figure 3. (a) Cross-section of the north-central Cascadia Margin in southern Washington showing the Juan De Fuca oceanic plate subduction under the North American plate and (2) relative positions of the deformation front or buried trench, the uplifted Coastline and Coast Range, the forearc valley, and the Cascade Range volcanic arc. (b) Diagram of vertical displacements during inter-seismic strain accumulation and co-seismic strain release. Co-seismic subsidence is recorded in coastal marshes in the north-central Cascadia margin (northern Oregon and Washington) but the $1^{\text {st }}$ zero-isobase intersects the coastline in the south-central Cascadia margin [10]. 


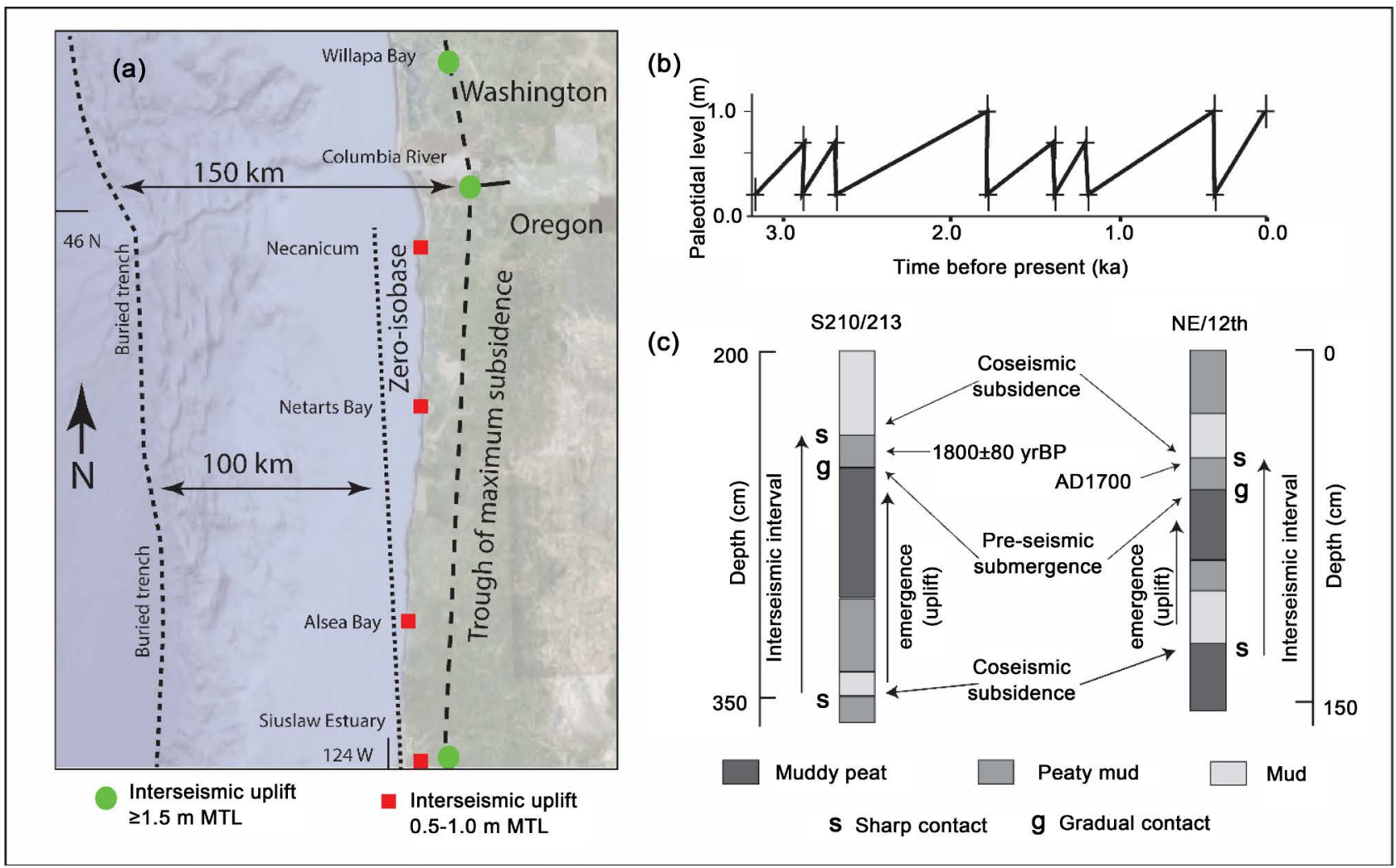

Figure 4. (a) Tidal marsh localities that record $\sim 0.5-1.0 \mathrm{~m}$ of interseismic uplift and co-seismic subsidence occur between the $1^{\text {st }}$ zero-isobase and the maximum trough of co-seismic subsidence in the northern Oregon coast. (b) A time series of interseismic uplift and co-seismic subsidence cycles are shown for the last $3.2 \mathrm{ka}$ in the tidal salt marsh of Netarts Bay (a). Most of the interseismic uplift apparently occurs in the first 200 - 300 years, as the longer duration intervals (2.6 - $1.7 \mathrm{ka}$ and 1.1 - $0.3 \mathrm{ka}$ ) do not show proportionately greater net uplift. (c) Pre-subsidence events are shown in two combined pairs of tidal marsh cores from the Siuslaw River estuary cores 210/213 [22], and the Necanicum River estuary, cores NE and 12 $2^{\text {th }},[23]$ [24]).

\subsection{Horizontal Strain Measurements}

The horizontal strain is the normalized change in distance between two material points [e.g., [26]]; a negative number indicates shortening, and a positive number indicates an extension. The larger the absolute value of the number, the greater the amount of horizontal shortening or extension. We measure the distance between two fixed GPS antennae daily, and any statistically significant change in the length over a period of several years is taken to be the average annual strain (see Methods section below), which is a close approximation to the strain rate.

The elastically recoverable portion of the strain, responsible for the release of energy during an earthquake is hard to determine because crustal materials inelastically deform at the timescale of earth-quake recurrence intervals [e.g., [27]]. Ninety-seven percent of the observed co-seismic strains from the 2011 Tōhoku, Japan, earthquake, were in the range of $10^{-6}$ to $10^{-5}$ [5]. If these strains are representative of large subduction-zone earthquakes, then that magnitude of recoverable elastic strain can accumulate in about 100 years from strain rates of about $10^{-7} a^{-1}$.

As will be shown in this article, such active strain rates (up to $\sim 10^{-7} \mathrm{a}^{-1}$ ) are 
currently measured in west-east baselines in the western Cascadia margin. It should be noted that the relatively short durations of horizontal baseline strain reported here, averages measured over several years in this study, might not represent the entire duration of the current inter-seismic interval, $\sim 300$ years duration since the last rupture at $\mathrm{AD} 1700$ [18]. Longer time scales of horizontal strain (centuries to thousands of years), which could yield inelastic strain deformation, are not addressed by these multi-year GPS baseline strain records.

At the other end of the time domain is the concern about very-short-term variations in apparent GPS station positions. It is well established that there are periodic variations in the GPS solution due to atmospheric and orbital considerations [28]. It is assumed that trends if measured over two years or more, will overcome these very-short-term variations and yield the average length changes over the several years' period. Verification of GPS station velocities, or the rates of baseline length changes, are established by statistically significant linear trends in the GPS station position data [1].

\subsection{ETS and Other Aperiodic GPS Velocity Affects}

It has been reported that Episodic Tremor Slip (ETS) events found in some Cascadia margin localities [29] affect the apparent horizontal velocity of GPS stations at monthly time scales. Summing of the apparent ETS events yields lower average east-velocities than the inter-ETS velocities [29]. To date, we have not been able to detect any significant changes in horizontal strain in our GPS baselines during reported ETS events (see Results section below). However, starting in 2015, these authors noticed that several baselines in western Washington State and in Vancouver Island (Figure 2), recorded decreased rates of baseline horizontal strain. Because it is unclear whether these strain rate anomalies are larger than average yearly cycles, or are part of a longer-term trend, we cut-off our data analysis for this article in January 2015. These 2015 and onwards strain rate anomalies will be examined more closely in future work, but the apparent effect was to lower the average changes in strain along the impacted GPS baselines. Additional work is required to establish the potential for spatially-variable episodic changes in horizontal strain accumulation based on multiple GPS baselines in continuous transects in the Cascadia margin.

\section{Methods}

\subsection{Horizontal Strain}

In previous work using the fixed GPS network in the Pacific Northwest [1] a series of West-East transects were selected to give strain profiles in linked baselines that extended from the coastline to the Cascade Mountains. The strain was larger than expected inland from the deformation front, so here we extend the existing lines to the East, and add new lines across Vancouver Island to the North, and across Northwestern California to the South (Figure 2).

The lines are oriented E-W and N-S so that they are at an angle to the ex- 
pected principal shortening direction permitting the principle shortening direction to be better determined. A new quadrilateral (for determination of the direction of principle strains) was added in Northern California (Mendocino quadrilateral) located west (landward) of the San Andreas transform system (Figure 2).

The data used in this article were collected from several sources: Daily RINEX files were obtained from the Pacific Northwest Geodetic Array [3], NOAA Continually Operating Reference stations [30] and the Plate Boundary Observation Stations [4], along with the precise ephemeris files from the International GPS Service (IGS) [31]. These data are processed using vecsol, [32], which is part of the GPSTK toolkit [33]. Vecsol solves for the baseline vector between two stations. During processing, one station is designated as the start of the vector, and the other at the end. The baselines are processed twice, using each end as the starting point of the vector and the other station is at the end-point, and the two baselines are compared for consistency. Typically, solutions are calculated for several years to look for the long-term trends in changes in the baseline. At least two years of data are needed to ensure the trend is not influenced by annual variations in baseline lengths [28]. The baseline vectors are stored in a database and analyzed using R [34].

Scatter plots are examined for outliers and may be removed from the solution. In most cases the outliers, once removed, do not change the significance or value of the solution. Baselines are also processed using different time periods to check for consistency over time.

To look for a trend in the data, the $\mathrm{R}$ function rlm (part of the MASS package) is used; this regression includes the ability to minimize the effect of outliers. If a significant trend is found in the data (as determined by the $t$ - and $F$-test results generated by rlm), the slope of the line is expressed as the average change of length per year. This is converted to a strain to calculate the average strain per year.

For the purposes of this article, we name the distance between two GPS stations as baseline segments, and a collection of linked baselines is a transect. The locations of baseline segments and grouping of baseline segments into transects are shown in Table A1 through Table A3 the Appendix.

Examples of two baseline segments are shown in Figure 5. The plots show the variation in baseline lengths over several years. Variations in baseline length between stations P154 (Happy Camp, California) and P786 (Gasquet, California) are from 2010 to 2016. There are 3274 baseline lengths used in the regression. The baseline length is $51.7 \mathrm{~km}$, and the regression indicates the baseline is getting shorter by $3.35 \mathrm{~mm}$ per year, which is an average strain of $-6.47 \times 10^{-8}$ each year in an almost West-East direction. The variation in baseline length between stations BCOV (Beaver Cove, Vancouver Island, British Columbia, Canada) and ELIZ (Eliza Dome, Vancouver Island, British Columbia, Canada) from 2008 to 2016. There are 5963 baseline lengths used in the regression. The baseline length 


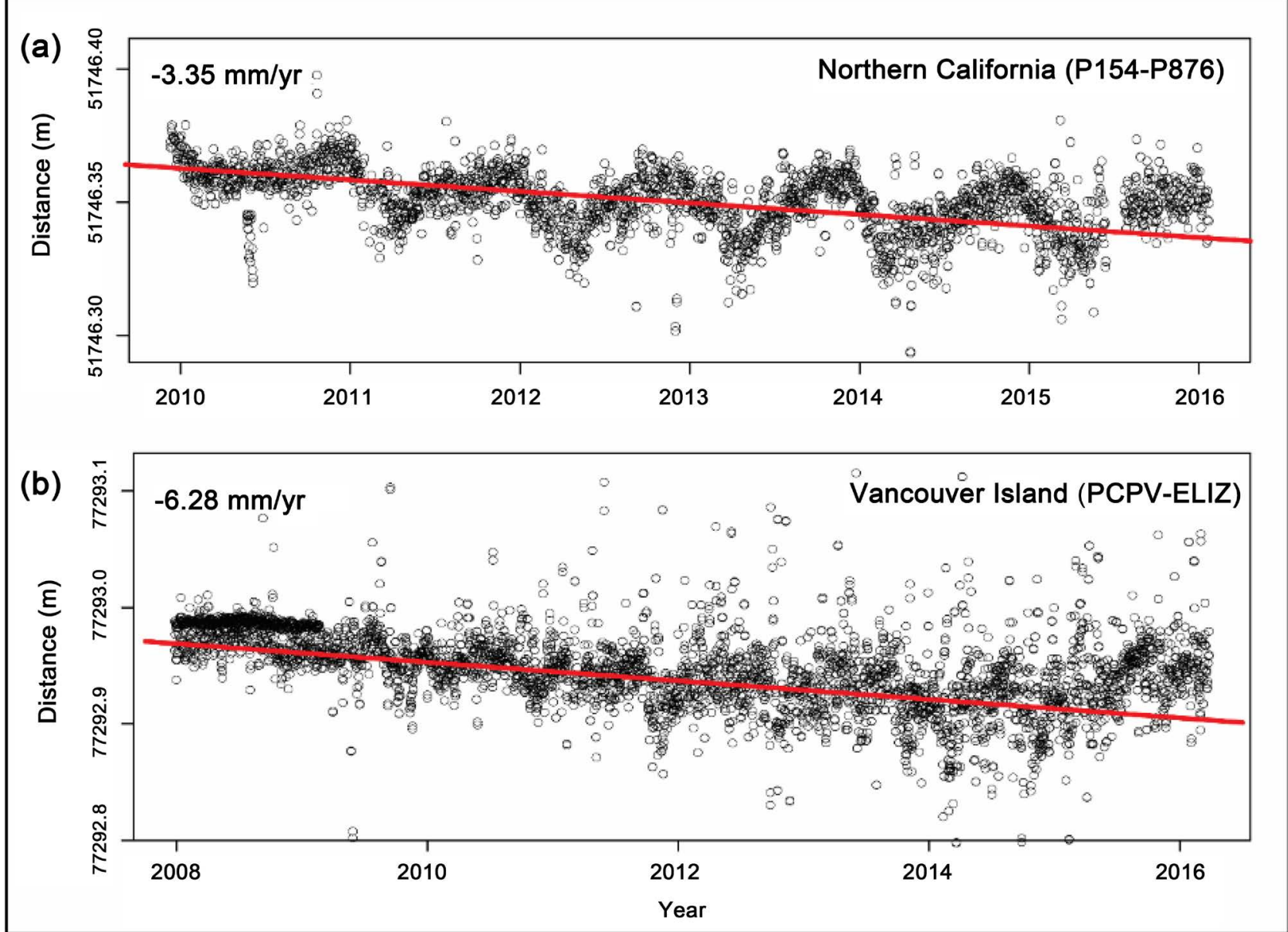

Figure 5. Illustration of trends in line from (a) Northern California, and (b) Northern Vancouver Island. The Northern California (P154-P786) line shows the annual variation, but the long-term shortening of the line. The Vancouver Island line (BCOV-ELIZ) shows more scatter, but the trend of the line is clear and corresponds to an average change of $6.6 \mathrm{~mm}$ per year since 2008 .

is $77.3 \mathrm{~km}$, and the regression shows the baseline is getting shorter by $6.28 \mathrm{~mm}$ per year, which is an average strain of $-8.13 \times 10^{-8}$ each year in a nearly margin-normal direction (the direction from BCOV to ELIZ is $15^{\circ}$, or $15^{\circ}$ East of North). Station locations are shown in Figure 2.

\subsection{Relative Rates of Vertical Displacements}

The vertical component of a GPS solution generally contains the largest uncertainty of any component of the position solution [e.g., [35]]. Vertical strain cannot be determined because we only have one material point at any GPS station. Instead, we use the trends in the vertical solution at a station, reported as the vertical velocity. These trends provide indicators of differences in relative vertical displacement between stations for a given period.

We focus on the vertical velocity because we lack any absolute measurement datum. Vertical deformation could be a combination of isostatic uplift, thickening due to shortening of the crust (as suggested by the horizontal strains), buckling of the continental crust, or downward drag of the upper-plate by the subducting lower plate. It is possible for all sites in an area to be going up variable 
folding, plate thickening, buckling, etc. To differentiate between local and regional processes of vertical displacement the actual values of up or down are not as important as the relative values in areas of interest.

The vertical velocities were obtained from the Pacific Northwest Geodetic Array [3], and the Plate Boundary Observation Stations [4]. The two data sets were combined, and the mean vertical velocity for the combined dataset determined. The mean vertical velocity was subtracted from each site vertical velocity to get the difference from the mean. The velocities were calculated from periods between 2006 to 2016. Velocity values are provided in millimeters per year ( $\mathrm{mm}$ $\left.\mathrm{yr}^{-1}\right)$.

\section{Results}

Here we present results from the measurement of horizontal strain along transects and in quadrilaterals (Figure 6) and vertical GPS velocities from 320 independent stations. The horizontal-strain results are presented below in sections 4.1-4.3. The vertical velocity data are presented in section 4.4.

\subsection{New Horizontal Strain Values}

The horizontal strain results from the newly added west-east and north-south GPS baseline transects (Figure 2 and presented in Table A1). Strains in the new west-east baselines range from $10^{-9}$ to $10^{-6}$ and average $10^{-7} \mathrm{a}^{-1}$. An annual strain of $-1.0 \times 10^{-7} \mathrm{yr}^{-1}$ would correspond to a shorting of one centimeter per $100 \mathrm{~km}$ baseline distance per year. The annual strain values in the newly added north-south baseline, located landward of the Cascade volcanic arc, range from $10^{-9}$ to $10^{-7}$ and average about $10^{-8}$.

\subsection{Horizontal Strain Patterns}

Figure 6 summarizes the magnitude of the strain across the region from both new and previous baseline measurements. Green represents shortening and red extension. The width of the baseline represents the magnitude of the strain. The location of the highest strain, which is shortening in Figure 6(a) $\left(-5.00 \times 10^{-7}\right.$ to $\left.-9.99 \times 10^{-7} a^{-1}\right)$, occurs at the northern end of the Puget sound. The lowest significant strains are all shortening. These smallest strains are located on the east side of the Olympic Mountains and in the forearc valley in northern Oregon. The extension is locally distributed, in short, disconnected, baselines, as shown in Figure 6(b). In the section below the new GPS, baseline results are reported separately.

New baseline strain data (Figure 6) are summarized in two groups, as based on baseline annual strain rates. In the west-east transects, the largest annual strain rates are all in shortening baselines $\left(10^{-7} a^{-1}\right)$ and are found in northwest Washington. The annual strains decrease to the north in Vancouver Island $\left(10^{-8}\right.$ $a^{-1}$ ) where baselines are orientated generally northwest-southeast, which is perpendicular to the local coastline and the buried offshore trench (Figure 1 and 

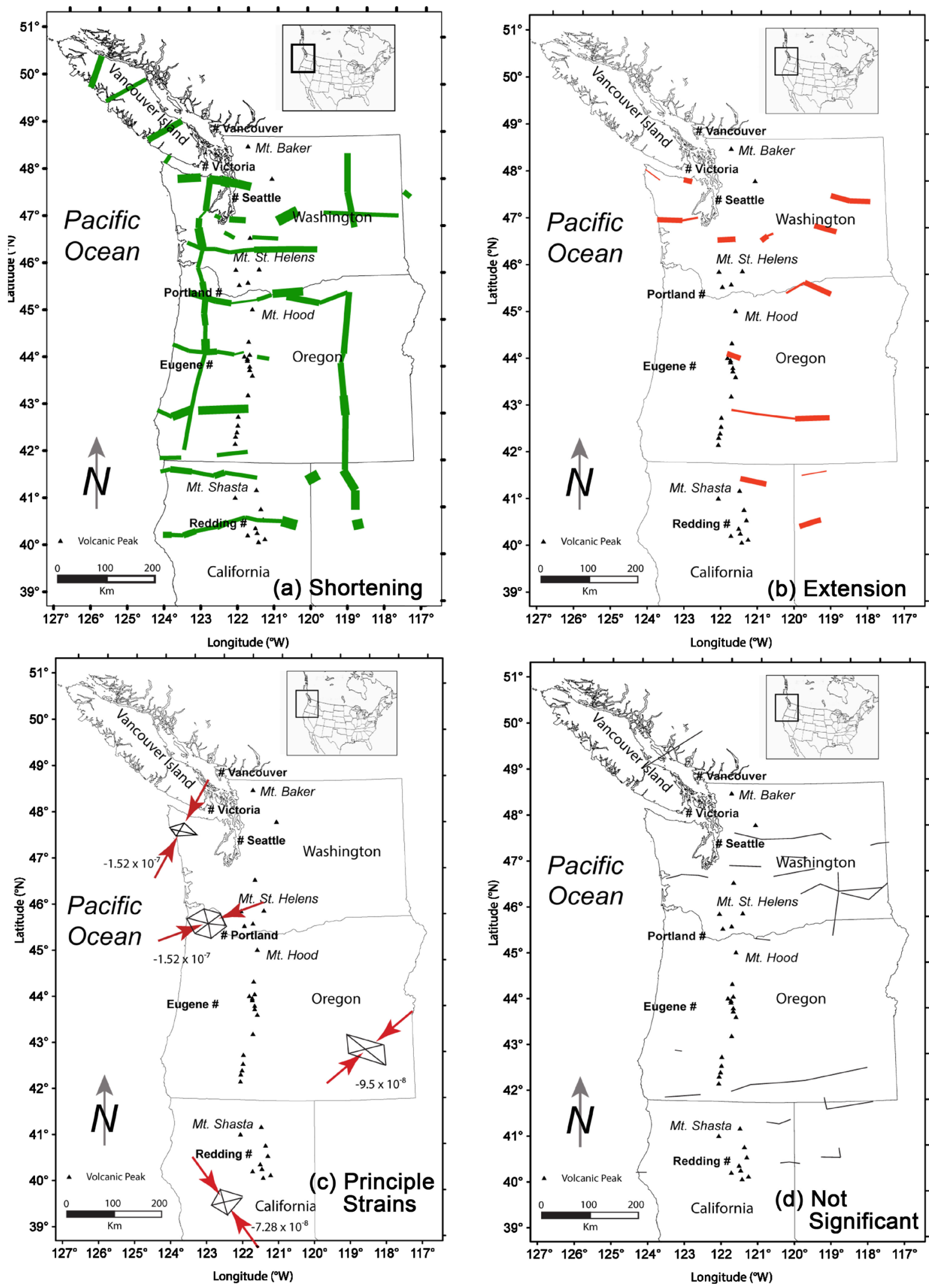

Figure 6. Horizontal strain measurements from combined new and previous work in the Cascadia margin. The thickness of the baseline (line) represent the absolute value of the strain magnitude. (a) Distribution and relative magnitude of shortening. (b) The distribution and magnitude of extension, (c), The orientation and magnitude of the principle strains, the red arrows represent the direction of maximum shortening, as determined using a strain quadrilateral. (d) Lines with no statistical change in length. 
Figure 6). Annual strain rates in the west-east baselines in northwestern-most California are also on the order $10^{-8} a^{-1}$. Several baselines located near the eastern ends of the west-east transects in southern Oregon and northernmost California show extension. These baselines are not thought to represent rifting but rather the secondary effects of dominant north-south compression. This interpretation is based on the dominant north-south shortening baselines shown for the new north-south transect, which is located well landward (east) of the Cascade volcanic arc. Though relatively small in magnitude $\left(10^{-8} a^{-1}\right.$ to $\left.10^{-9} a^{-1}\right)$, the new west-east baselines located east of the Cascade volcanic arc in Washington and northernmost Oregon demonstrate shortening strain to distances of $\sim 400$ $\mathrm{km}$ landward) of the buried trench. The new GPS baseline data from the central Cascadia margin confirm prior observations [1] that demonstrated differences in baseline shortening between across-margin and along-margin transects. The largest strains are found in E-W transects, but there is a significant strain on the eastern side of the Cascade Range, especially along the N-S transect. The new transects across Vancouver Island show shortening perpendicular to the margin along the whole length of Vancouver Island. The strains are about $10^{-8} \mathrm{a}^{-1}$. The new baselines from southern Oregon and Northern California show East-West shortening, again about $10^{-8} \mathrm{a}^{-1}$.

In this section, the previous GPS baseline strain data [1] are combined with the new baseline strains (Table A2) to represent regional strain patterns in the central Cascadia margin. The locations of the highest annual strain rates $(-5.00 \times$ $10^{-7} a^{-1}$ to $-9.99 \times 10^{-7} a^{-1}$ ) occur in several west-east baselines, northeast of the Puget sound region, between Seattle and the Olympic Coast Range (Figure 6).

The second-highest strain rate group $\left(1.00 \times 10^{-7} \mathrm{a}^{-1}\right.$ to $\left.4.99 \times 10^{-7} \mathrm{a}^{-1}\right)$ is divided between west-east transects in northern Washington State and Oregon State. These transects are dominated by shortening, but some west-east transect segments in central western Washington show localized extension. The origin(s) of the localized extensions are not known now. However, if the extensional strain is elastic, then the co-seismic release of these strains could be added to the co-seismic release of shortening strains under conditions of a major regional rupture. The next-highest annual strain group $\left(5.00 \times 10^{-8} \mathrm{a}^{-1}\right.$ to $\left.9.99 \times 10^{-8} \mathrm{a}^{-1}\right)$ is mostly located along the north-south transect on the east side of the Cascade Range in Oregon and Washington. The group of annual strain rates in the range of $1.00 \times 10^{-8} \mathrm{a}^{-1}$ to $4.99 \times 10^{-8} \mathrm{a}^{-1}$ are mostly shortening and they occur in west-east transects just south of the Olympic Coast Range. Several segments of the north-south Coast Range transect also show these smaller magnitudes of strain. The smallest annual strain rates measured in this study $\left(\leq 10^{-9} \mathrm{a}^{-1}\right)$ generally occur in shortening west-east transects on the east side of the Cascade volcanic arc in northern Oregon.

\subsection{Principle Shortening Directions}

Several braced quadrilaterals are used to establish principle shortening directions at key locations in the study area. For this article we use previously published 
quadrilaterals (50 to $100 \mathrm{~km}$ axis distance) from NW Olympic Peninsula, Vernonia and Burn Junction (southwestern Oregon) [1] and new data from a quadrilateral in northern California (Figure 6(c)). The Mendocino quadrilateral is located south of the triple junction between the Pacific Plate, the North American Plate, and the southern part of the Juan de Fuca plate or Gorda segment. The northern California quadrilateral represents modern strain in the North American plate near the San Andreas transform plate boundary.

Principal strain axes in the braced quadrilaterals in the central Cascadia margin demonstrate principal shortening in northeast-southwest directions, confirming oblique convergence strain in this part of the subduction zone. In contrast, the braced quadrilateral from northern California demonstrates a northwest-southeast direction of principal shortening, reflecting strain near the right-lateral San Andreas transform boundary.

\subsection{Relative Rate of Vertical Displacements}

The vertical velocities of 321 GPS stations, measured over about a decade period, range from -9 to $+3 \mathrm{~mm} \mathrm{yr}^{-1}$ in the study area. The mean of the measured velocities for the study area is calculated to be $-1.7 \mathrm{~mm} \mathrm{yr}^{-1}$. Taking the mean to be a zero-velocity value, we find that 161 stations show a relative upwards velocity, 79 stations show zero velocity, and 81 stations show a relative downwards velocity. For the purposes of this article, we refer to the relative upwards velocities as relative uplift and relative downwards velocities as relative subsidence.

GPS station vertical velocities for the central and southern Cascadia margin are contoured in Figure 7. Contouring tends to smooth out local variability for spatial analysis, but relative values (i.e., relatively up, or relatively down) of the reported vertical velocities are of greater certainty than given velocity values. The positive areas (shades of red in Figure 7) represent GPS sites that are moving up relative to the mean, and negative areas (shades of blue) are moving down relative to the mean. The Cascade volcanic arc is generally associated with relative subsidence, but several volcanic areas, including Mount Baker and Mount Saint Helens in Washington, Mount Hood in Oregon, and Mount Shasta in California, are associated with hotspots of localized relative uplift. Two other apparent anomalies of relative uplift are associated with topographic highs in the Olympic Coast Range of Washington and in the central Coast Range of Oregon. A very small area of relative uplift occurs at the eastern edge of Coast Range near a major bend in the lower Columbia River. Two large anomalies of vertical displacement occur at the coast, including relative subsidence at Willapa Bay, Washington, and relative uplift at the border between California and Oregon border. Smaller bullseyes of relative subsidence occur at Neah Bay, in the northwest corner of Washington Pacific Coast, and in southeast Oregon and southeast Washington.

Broader patterns of vertical deformation in the central Cascadia margin are characterized by heterogeneity of relative uplift and subsidence. A discontinuous belt of relative uplift is prominent along the coastline but that pattern is strongly 


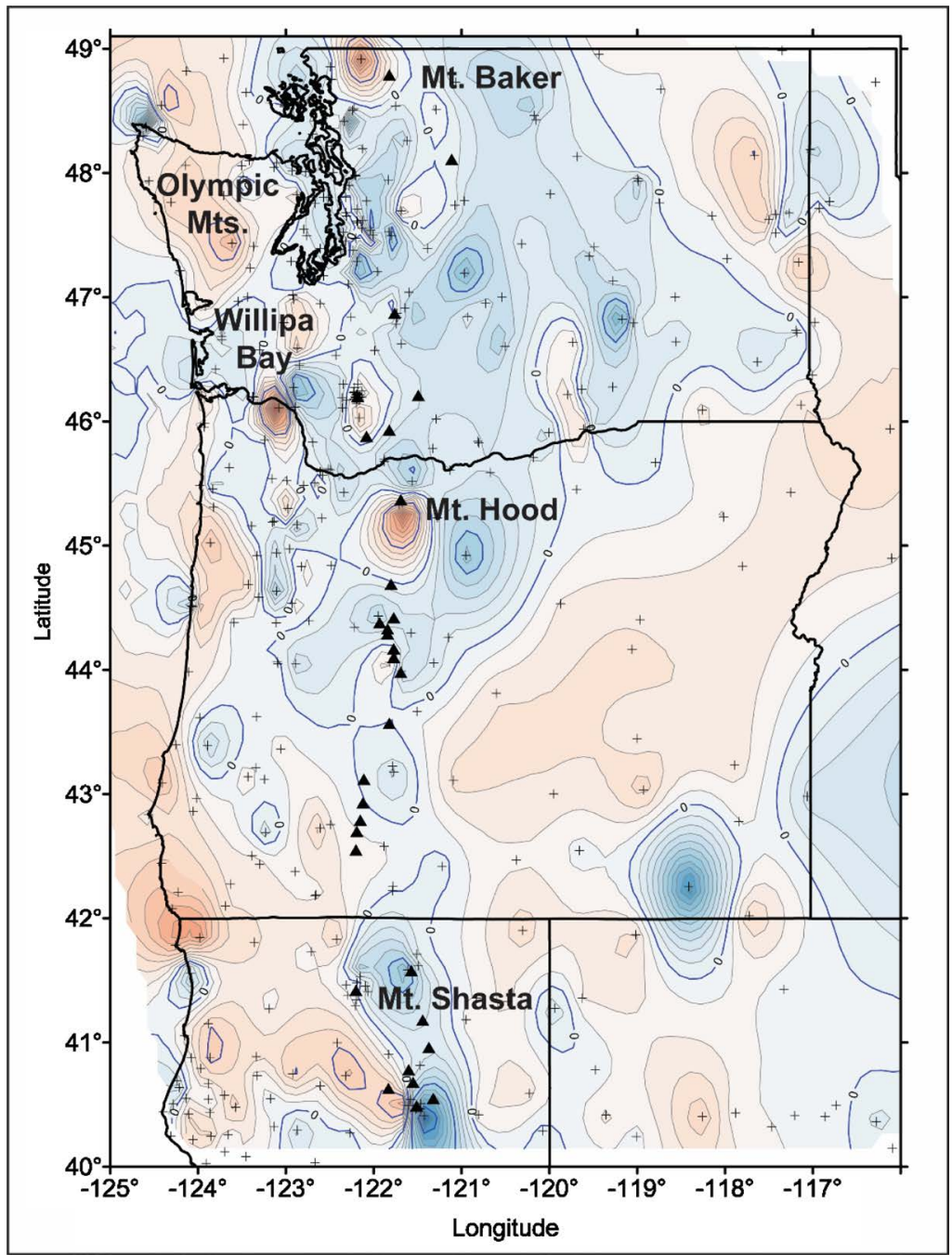

Figure 7. A Map of GPS vertical velocity sites (solid dots) and velocity contours (colors) given at $1 \mathrm{~mm} \cdot \mathrm{yr}^{-1}$ velocity intervals, relative to the study area mean (Table A2). The mean is defined as zero velocity for this article. Positive values (warm colors) indicate that GPS sites are moving upwards relative to the mean and negative values (cool colors) mean that the GPS sites are moving downwards relative to the mean.

dissected by relative subsidence along the coast in southwest Washington. The discontinuous belt of relative uplift along parts of the coast transitions to a discontinuous belt of relative subsidence in the forearc valleys east of the Coast Ranges. The relative subsidence is more continuous along the Cascade volcanic range in California, Oregon, and Washington.

\section{Discussion}

In this section, we address the relations between modern horizontal strain measurements from GPS baselines and vertical displacements from GPS vertical velocities and longer-term geodetic surveys and paleo-tidal marsh records in the Cascadia margin. These different data sets are used to establish conditions of elastic strain and/or vertical displacement in the large Cascadia seismogenic structure during the late stage of the current inter-seismic interval. 


\subsection{Horizontal Strain}

Horizontal strain measurements of shortening and extension in the Cascadia margin (Figure 6) are compared to establish regional patterns of upper-plate strain orientations and magnitudes on the landward side of the subduction zone. During the time periods that the GPS base station data were collected, generally 2006-2016 (Table A2) no anomalous large-scale strain reversals were observed that lasted longer than the annual cycles common to continuous base station records (Figure 5). For example, a reported tremor and slip event (ETS) in the northern part of the central Cascadia margin, near Seattle, Washington [36] was not recorded in the west-east GPS baselines that cross that locality (Figure 6). It is possible that the ETS events that reportedly occurred during 2006-2014 period were located between the GPS baselines used in this study. However, an anomalous change in strain rate was observed in 2015 in several GPS baselines from the northwest part of the study area, but no corresponding ETS events were reported for that period. Additional monitoring of those baselines is underway to establish the potential duration and magnitude of the localized changes in strain rates. In summary, the GPS baseline data reduction and analyses methods reported in this study have not confirmed any ETS events, by corresponding changes in surface horizontal strain rates, during the period of GPS base station monitoring.

The GPS baseline stain analyses presented here differ from other studies of GPS horizontal velocities [37] in that no plate motions or rotations, and their inherent uncertainties, are utilized in the GPS baseline analyses. A limitation of the GPS baseline approach is the limited spatial resolution of the baseline lengths, $\sim 50 \mathrm{~km}$ between available GPS stations (Table A2). These length scales cannot resolve strain within discrete upper plate surface faults or smaller-wave-length folds. Redundancy of GPS baselines, within a long transect or in parallel, at spaced $(\sim 100 \mathrm{~km})$ intervals along-margin (Figure 6$)$, helps to confirm broader trends of shortening or lengthening. Future analyses of the smaller-scale heterogeneity between baselines will require increased density of GPS stations in the Cascadia margin. And, to date, no GPS stations are established offshore of the Cascadia margin coastline. The GPS baseline strain method is suited to regional scale analyses of the landward portion of the Cascadia margin. The higher strain rates that are reported in this article are assumed to be largely elastic, so they are potentially indicative of co-seismic strain energy release and earthquake magnitude, as discussed later in section 5.1. In this section, we address the regional patterns of modern horizontal strain in the Cascadia margin.

At the regional scale, four patterns of modern horizontal strain are apparent in the study area. Firstly, shortening strains are measured to the north and to the south, respectively, of the central Cascadia margin in Vancouver Island, British Columbia, and southern Oregon and northernmost California (Figure 6). Both the Explorer plate segment to the north and the Gorda plate segment to the south of the central Cascadia margin (Figure 1) demonstrate substantial modern convergent strain $\left(\sim-5 \times 10^{-8} a^{-1}\right.$ to $\left.-5 \times 10^{-7} a^{-1}\right)$, and can support or even in- 
itiate major coseismic ruptures. Secondly, regional shortening strain (west-east) is observed in the central Cascadia margin to a landward distance of $\sim 400 \mathrm{~km}$ from the deformation front or buried trench. The shortening strain magnitudes generally decrease with increasing distance landward from the Coast Ranges, indicating strain origins from horizontal stresses, initiated at the coupled zone and transmitted through the upper plate (Figure 8). Small increases in shortening strain are locally associated with the Cascade volcanic arc, suggesting a coupling of the plate interface against the western side of the thickened upper-plate under the volcanic. Thirdly, the highest shortening strains $\left(-5 \times 10^{-7}\right.$ to $\left.-9 \times 10^{-7} \mathrm{a}^{-1}\right)$ are found in a transect located north of the Olympic Coast Range. This locality is situated at a major bend of the convergent margin, but it is not known whether the highest strain rates there are due to (1) increased convergent stresses, (2) thinning of the Siletzia terrain [38], (3) aseismic creep on low-angle structures in the upper plate, and/or (4) other unknown mechanisms. Fourthly, west-east shortening strains $\left(\sim 10^{-7} \mathrm{a}^{-1}\right)$ are about an order of magnitude larger than north-south shortening strains $\left(\sim 10^{-8} \mathrm{a}^{-1}\right)$ in the Coast Range. The smaller north-south shortening strains in the Coast Range are thought to reflect oblique convergence in the central Cascadia margin [1]. However, the north-south shortening strains east of the Cascade volcanic arc $\left(\sim 10^{-8} \mathrm{a}^{-1}\right)$ are about an order of magnitude larger than corresponding West-East shortening strains $\left(\sim 10^{-9} a^{-1}\right)$ so the larger north-south strains located along the eastern margin of the study area are not due to plate convergence. Rather, the relatively larger north-south strains on the east side of the study area could represent an eastward (landward) shift of the north-south regional strain from the transform systems that bound the Cascadia Margin to the south and north (Figure 1), as discussed further below.

Braced quadrilaterals at key localities establish principal shortening directions in the Cascadia margin (Figure 6). The two quadrilaterals (NW Olympic and Vernonia) in the western (seaward) portion of the central Cascadia margin demonstrate principal shortening in the NE-SW orientation. These directions are consistent with oblique plate convergence (Figure 1) and dominant strain in west-east GPS baselines relative to north-south baselines in the Coast Ranges. A

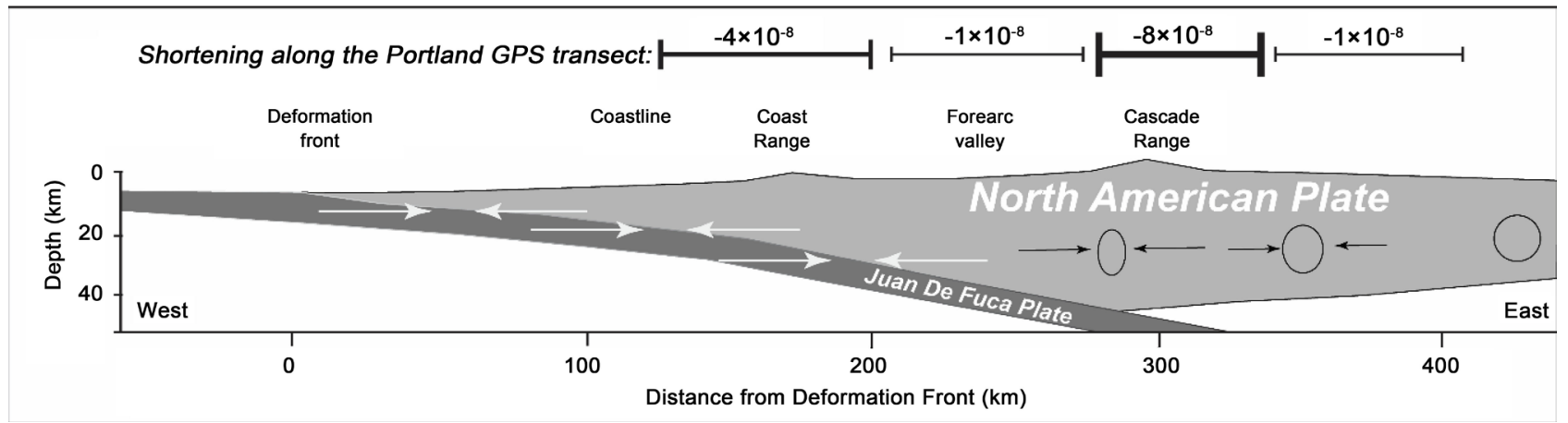

Figure 8. Cross-section diagram of the central Cascadia margin subduction zone, including horizontal stresses (arrows) and annual strain rates (line segment thickness proportional to shortening rates) in a west-east transect (through Portland, Oregon) (Figure 1, Figure 6; Table A2). Lower crust bottom depths are from [39]. Ellipses represent relative strain magntudes. 
new quadrilateral (Mendocino), located south of the triple junction between the North American plate, the Pacific Plate, and the Gorda plate segment shows principal shortening in a NW-SE orientation, approximately perpendicular to the principal shortening direction in the western portion of the central Cascadia margin. These results are at odds with inferences that stresses in the San Andreas transform system could trigger major ruptures of the Cascadia margin [40], especially in the central Cascadia margin, where the highest across-margin strain rates occur. Some north-south compressional stress from North American plate areas located east of the triple junction in northern California could be directed northward leading to (1) north-south shortening at the eastern side of the study area, as noted above, and (2) localized extension in the eastern portions of several west-east transects in the southern Cascadia margin. We take the major change in dominant shortening directions at the eastern side of the study area to represent a bounding condition to significant convergent elastic strain in the Cascadia margin. The change in dominant shortening directions, and the inferred corresponding stress regimes, at $300-400 \mathrm{~km}$ distance landward of the buried trench, serves as an eastern boundary to the Cascadia seismogenic structure.

\subsection{Rates of Vertical Displacement}

The substantial modern vertical deformation in the central Cascadia margin extends $\sim 300 \mathrm{~km}$ landward from the coast or $\sim 400 \mathrm{~km}$ from the buried trench in the central Cascadia margin (Figure 1). There is substantial uncertainty in the measured velocity values (see Methods) but the signs (+ or -) of the displacements, as measured over a decade in duration and relative to the study area mean, are considered to be accurate. The apparent vertical deformation is heterogeneous over shorter scales (50 to $100 \mathrm{~km}$ ) but does generally show decreasing gradients of change (wider spaced contours) east of the Cascade volcanic arc, suggesting decreasing vertical deformation with increasing distance landward from the Coast Range (Figure 9(a)). A possible exception to this overall pattern is the apparent linear zone of relative subsidence associated approximately with the volcanic arc. A potential increased recoupling of the subducting plate may be responsible for the abrupt edge of relative subsidence along the thickened upper-plate under the volcanic arc (Figure 8).

The reported GPS relative uplift/subsidence rates along the coast are not consistent with the long-term records of inter-seismic-uplift, or the lack of it, as shown by tidal marsh paleo-tidal level changes (Figure 9). For example, the GPS relative uplift velocities on the coast average $1-2 \mathrm{~mm} \cdot \mathrm{yr}^{-1}$, so over $\sim 200$ years that would be $300 \mathrm{~mm}$ or 30 centimeters. If the GPS relative uplift velocities are accurate than the current displacement rates would be insufficient to account for the $1.0-2.0 \mathrm{~m}$ of inter-seismic uplift, since the last Cascadia rupture, as recorded by tidal marshes in the zone of maximum co-seismic subsidence and inter-seismic uplift. More importantly, the signs $(+/)$ of modern GPS relative uplift and subsidence are not consistent with the long-term inter-seismic record of 

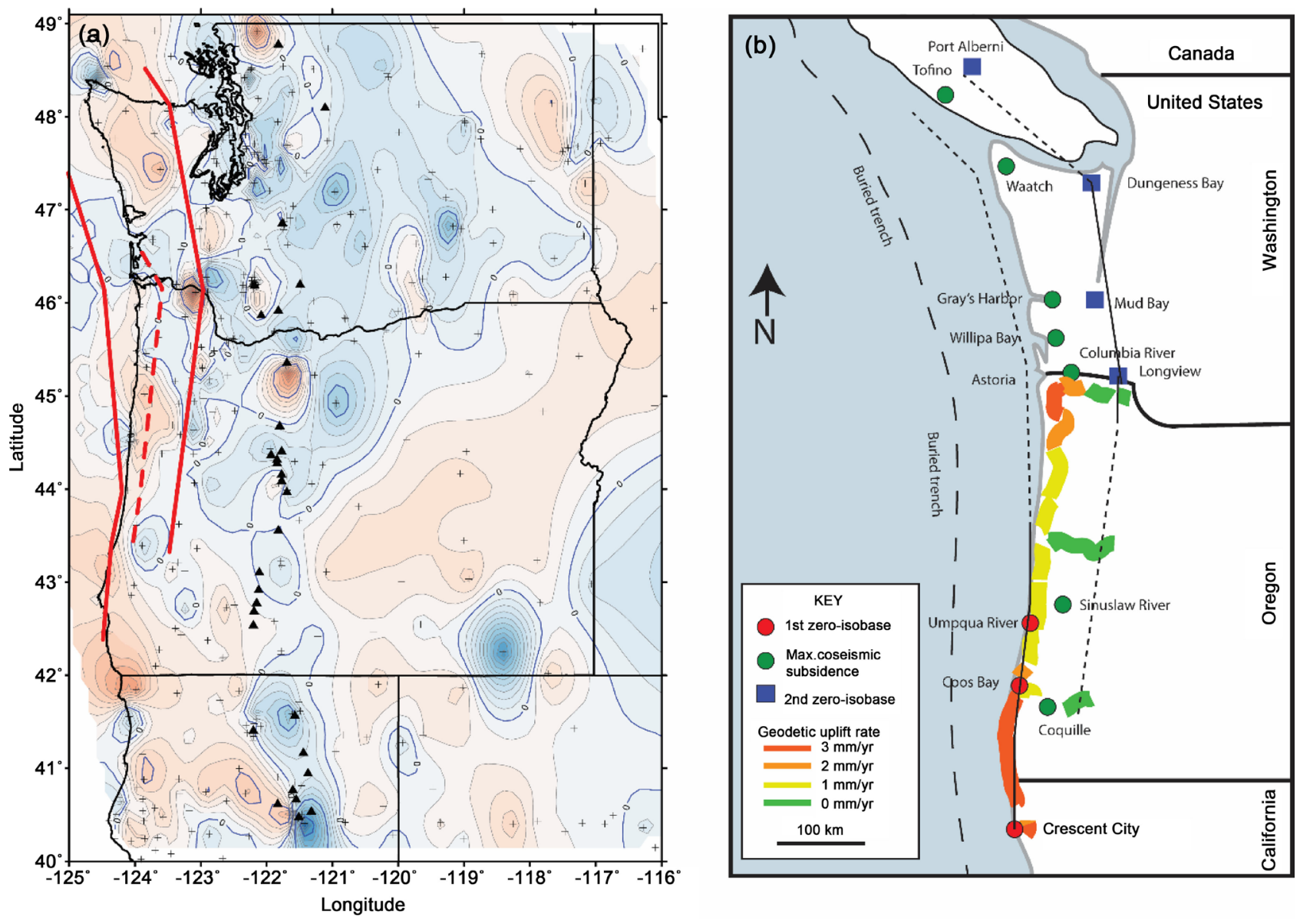

Figure 9. (a) Comparisons of modern GPS vertical velocity data with mega-fold zero-isobases (solid red lines) and the volcanic arc (solid black triangles) for spatial references. The left line ( $1^{\text {st }}$ zero-isobase) and the right line ( $2^{\text {nd }}$ zero-isobase) occur on either side of the zone maximum co-seismic subsidence (dashed line [19]. (b) Map of coastal coseismic-subsidence records (0.3 - 3 ka in age), zero-isobases, and summarized vertical displacement trends from 50-year geodetic releveling surveys [42]. Coseismic subsidence localities are named [10]. Geodetic survey segments are color coded by uplift rate ( $\mathrm{mm} / \mathrm{yr})$ [42].

post-seismic uplift at key localities. The zone of maximum co-seismic subsidence, and corresponding inter-seismic uplift, has an opposite sense of trend $($ sign +$)$ compared to the GPS relative subsidence contours (sign -) shown for the southwest coast of Washington at tidal marsh localities in Willapa Bay, Washington [19] [41]. The modern GPS coastal relative uplift anomaly at the California/Oregon coastal border overlies the $1^{\text {st }}$ zero-isobase of no co-seismic subsidence or inter-seismic uplift (sign 0) in the Elk Creek marsh at Crescent City, California [2]. If the modern GPS vertical displacement signs do not reflect the longer-term trends of post-seismic coastal uplift or the lack of it, as recorded in corresponding tidal marsh localities, then what do they represent? This question is addressed below following a discussion of similar findings from coastal geodetic releveling surveys [42]

A 50-year record of geodetic leveling surveys [42] along the Oregon coast is summarized in Figure 9(b). The geodetic surveys show variable uplift along the coast, with decreasing vertical deviations landward of the coastline in several short across-margin transects. The 50-year geodetic leveling survey results are 
generally consistent with the GPS velocity displacements along the Oregon coast, in that both independent data sets yield 1) positive signs (+) of coastal uplift, 2) approximately similar averaged uplift rates $\left(1-2 \mathrm{~mm} \cdot \mathrm{yr}^{-1}\right)$, and maximum relative uplift at the Oregon/California border and just south of the Washington/Oregon border. More detailed comparative analyses of modern GPS vertical displacements and geodetic leveling lines across the central Cascadia margin are warranted.

The 50-year geodetic leveling results (Figure $7(\mathrm{~b})$ ) were not previously compared [42] to long-term vertical displacement records that have been analyzed from tidal marshes in the area, as summarized in Peterson \& Cruikshank [19]. As previously noted, the high geodetic leveling uplift rates $\left(+3 \mathrm{~mm} \cdot \mathrm{yr}^{-1}\right)$ near the California/Oregon border are not consistent with zero-uplift recorded in tidal marsh records in the Elk Creek estuary at Crescent City, California. In summary, neither the GPS vertical velocity data nor the 50-year geodetic leveling uplift rates consistently reflect the previous $\sim 200$-year trends of coastal vertical displacements, as shown by tidal marsh records along the coast.

The lack of correspondence between the modern GPS vertical velocity trends and the long-term tidal marsh records of inter-seismic displacements along the coasts of Washington and Oregon (Figure 9(a)) are consistent with three previously unexplained phenomena in the central Cascadia margin. These include (1) the observation that long inter-seismic intervals do not maintain high rates of interseismic uplift after 200-300 years following co-seismic subsidence (Figure 4(a)), (2) some inter-seismic intervals show an opposite sign of tidal marsh development, reflecting gradual submergence, prior to co-seismic subsidence (Figure 4(b)), and most importantly (3) longer inter-seismic intervals do not correspond to the largest paleo-tsunami run-ups in Cascadia margin coastlines [11]. These phenomena can be explained by decreases in vertical displacement rates, and possibly locally reversed vertical displacement signs $(+/-)$, during a late stage of the inter-seismic interval as discussed below.

\subsection{Definition, and Implications of Late-Stage of Interseismic Strain}

Studies of coastal subsidence and uplift records from the Cascadia margin suggest that the inter-seismic interval (between earthquakes) can be broken into three broad stages. The early stage defined as the period just following an event where there is no definitive record of marsh emergence, due to recovery period of mash recolonization of subsided mud flats. Wang and others [27] suggest this stage represents a relatively short period of interplate-interface recoupling after the co-seismic rupture. We assume that such an early stage of little to no convergent strain would occur in the Cascadia margin for several decades after a major co-seismic rupture, such as after the AD1700 great earthquake (Figure $10)$.

Once the interplate interface was sufficiently recoupled in the Cascadia margin (early stage) then convergent strain began to accumulate in the upper plate. 


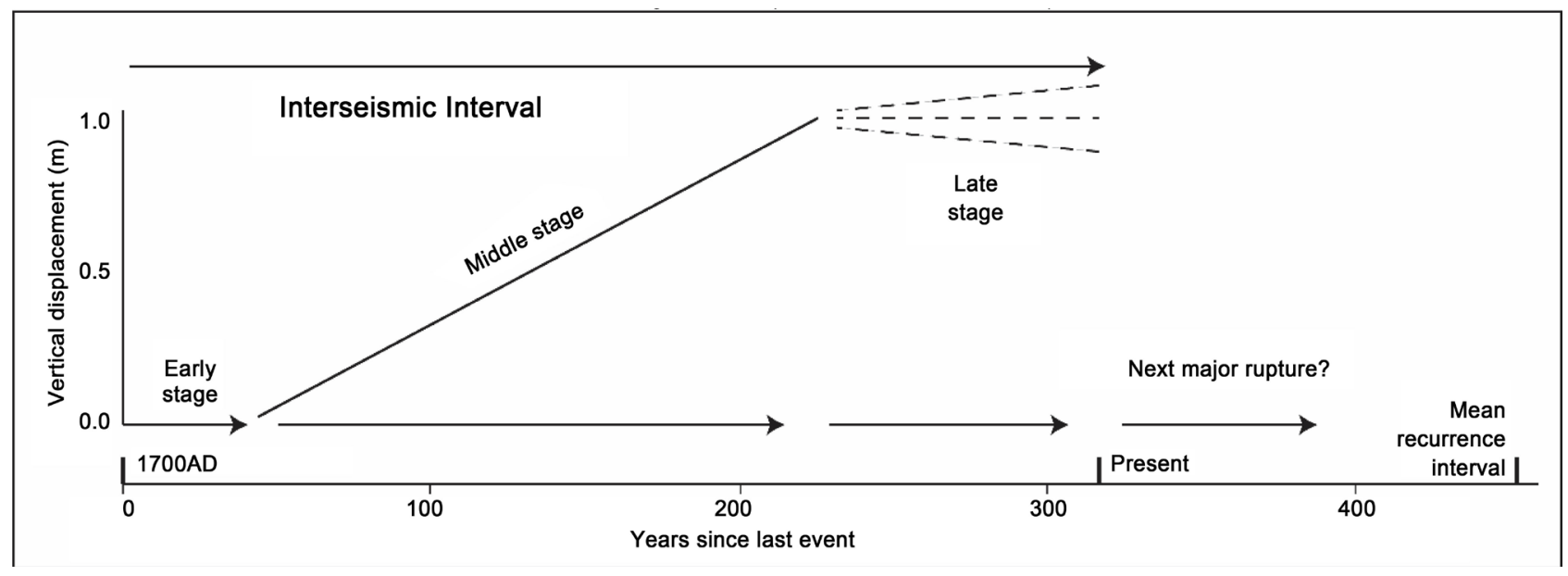

Figure 10. The three stage of the interseismic strain/displacement interval are shown between the last coseismic rupture at AD1700 and the present time ( 300 years interval). The early stage, possibly several decades in duration, is not well recorded by tidal marsh records of emergence, due to a period of marsh plant recolonization of the subsidised mud flats. The middle stage is well recorded in subsided tidal marsh sites at multiple localities along with the northern Oregon coast (Figure 4(a)). The late stage is recorded in some localities, such as at Necanicum, by a decrease in uplift rate, leading to pre-rupture submergence (Figure 4(b)), and in other localities, by GPS and/or geodetic records that are opposite in vertical displacement to the middle stage of tidal marsh uplift (Figure 9). The potential duration of the late stage of interseismic strain/displacement is not known, but sufficient horizontal strain could have already accumulated during the last 100 years in the central Cascadia margin to yield a Mw 9 event, as discussed below in section 5.4.

The prolonged middle stage of interseismic strain accumulation, possibly up to 200 years in duration (Figure 10) was recorded by high rates of interseismic uplift of tidal marshes that are located between the $1^{\text {st }}$ and $2^{\text {nd }}$ zero-isobases (Figure 3(b) and Figure 4(a)). The middle stage vertical displacements are widespread, reaching 100's of kilometers along-margin and 10's of kilometers across the margin. The long-term uplift rates are estimated to have exceeded $0.75 \mathrm{~cm} \cdot \mathrm{yr}^{-1}$ in the zone of maximum co-seismic subsidence, as based on; $>150 \mathrm{~cm}$ uplift $/ 200$ $\mathrm{yr}$ duration $=0.75 \mathrm{~cm} \cdot \mathrm{yr}^{-1}$ displacement rate. The middle stage of elastic strain accumulation yielded the mega-fold in the upper plate, which is in part, responsible for near-field tsunami excitation [21].

The current late stage of inter-seismic stain accumulation in the Cascadia margin is recorded by both GPS vertical velocities (this article) and the 50-year geodetic releveling surveys of the Oregon coast [42]. The two independent measures of current vertical displacement (late stage) differ in magnitude and spatial patterns from the previous mega-fold development (middle stage). The horizontal strain accumulation rates that are occurring during this late stage of the inter-seismic interval $\left(10^{-8} a^{-1}-10^{-7} a^{-1}\right)$, and certainly during the middle stage of coastal mega-fold displacement (Figure 10) in the Cascadia margin are sufficient to yield a large magnitude great earthquake, as discussed further below in Section 5.4.

The recognition of a late stage of strain/vertical displacement in the Cascadia margin bears directly on several aspects of hazard mitigation. Firstly, sufficient inter-seismic elastic strain has already accumulated, during the middle stage of the inter-seismic interval (Figure 10), to produce a large magnitude great 
earthquake. Secondly, the Cascadia margin is poised to excite a maximum-runup tsunami now. Indeed, the runup could decrease with possible ongoing/future relaxation of the mega-fold, during a prolonged late stage of the inter-seismic interval (Figure 10). Thirdly, previous probability estimates of earthquake magnitude and tsunami runup, based on inter-seismic interval durations are not relevant once the Cascadia margin has passed into the late stage of the inter-seismic interval. Finally, it is not known whether further/future rate changes in horizontal strain or vertical displacement will significantly precede the next major co-seismic rupture.

\subsection{Estimate of Earthquake Magnitude for the Central Cascadia Margin}

The energy released during an earthquake is thought to come from stored elastic strain energy [12]. To evaluate the relative magnitude of a great earthquake that could occur now in the central Cascadia margin we use the observed co-seismic strains from the 2011 Japan earthquake (400 km along-margin rupture length) as a measure of the strain energy released during a $\mathrm{Mw} 9.0$ subduction zone earthquake. If the observed modern strains over the last decade in the central Cascadia margin represent the average rate that strain can accumulate in the central Cascadia seismogenic structure (400 km width) then it would have taken about 100 years for the magnitude of the observed Cascadia strains $\left(10^{-8}\right.$ to $\left.10^{-7}\right)$ to match those observed resulting from the 2011 Japan earthquake $\left(10^{-6}\right.$ to $\left.10^{-5}\right)$. That is to say that, a $400 \mathrm{~km}$ along-margin rupture length of the central Cascadia seismogenic structure is apparently capable of generating up to a magnitude 9.0 earthquake after as little as 100 years of strain accumulation at the modern rates. However, the strain has been accumulating in the central Cascadia margin since the last megathrust rupture at AD1700 ( 300 years ago). The rheology of the crustal material is probably viscoelastic. At some point, the material reaches an equilibrium state, where strain energy is being added at about the same rate that energy is used in permanent deformation, aseismic slip and/or in short-term events such as ETS events, or micro-seismicity. An earthquake occurs when the stress/strain state changes, possibly propagated from a small initiation area, so that a sudden, rapid release of the stored elastic portion of the strain occurs throughout the affected seismogenic structure (up to $400 \mathrm{~km}$ width in the central Cascadia margin). We believe that a one-half rupture length $(400 \mathrm{~km})$ of the central Cascadia margin (800 km total length) has accumulated sufficient elastic strain energy during the last $\sim 300$ years since the last megathrust rupture at AD1700 to yield a Mw 9.0 great earthquake. Longer rupture lengths could increase the earthquake magnitude, based on modern convergent strain rates measured throughout the margin.

\section{Conclusions}

In this article measurements of convergent horizontal strain, as recorded in GPS station-to-station baselines over several years, have been extended north of the 
central Cascadia margin into Vancouver Island, British Columbia, Canada, and south of the central margin into southern Oregon and northern California. The modern accumulation of horizontal strain in the upper plate has also been observed to occur well landward of the Cascade volcanic arc, demonstrating a very wide seismogenic structure. Convergent (across-margin) strain dominates over north-south (along-margin) strain in the Cascadia seismogenic structure. However, north-south strain dominates landward of the convergent seismogenic structure, possibly representing a landward displacement of transform stress from the southern and northern boundaries of the Cascadia subduction zone. The upper plate serves as a capacitor, storing accumulated elastic strain throughout its thickness and width in the seismogenic structure. Dominant convergent-plate strain in the central Cascadia margin is nearly perpendicular to margin-parallel strain in the San Andreas transform area located south of the subduction zone triple junction. There is no modern strain evidence to suggest that major ruptures of the central Cascadia margin are triggered by stresses in the San Andreas transform system. Indeed, the greatest strain rates in the Cascadia margin currently occur in the central Cascadia margin, and a coseismic rupture there could propagate north and south to impact large inland metropolitan centers.

In this article, GPS station, vertical velocities are averaged over about a decade to establish upper-plate uplift and subsidence patterns relative to the study area mean. The vertical displacement patterns are patchy, but several regional patterns emerge. The Cascade volcanic range is associated with subsidence, except for local uplift anomalies at several volcanic centers. A narrow discontinuous belt of uplift is associated with the Coast Ranges in Washington and Oregon. Two important vertical displacement anomalies occur at the coast in southwest Washington (subsidence) and in the coastal border area between southwest Oregon and northwest California (uplift). The origins for these anomalies are not known, but they are inconsistent with long-term cyclic vertical displacement records from tidal marshes. For example, the southwest coast of Washington had experienced substantial uplift after the last Cascadia rupture $~ 300$ years ago, which is opposite to the current GPS vertical velocity sign (-). The tidal marshes near the Oregon/California border showed no co-seismic uplift or subsidence during the last Cascadia rupture, and no apparent post-seismic uplift or subsidence following that event. The modern uplift anomaly at the Oregon/California border is in contradiction with the lack of previous long-term inter-seismic uplift in the area. We interpret these inconsistencies to represent changes in the rate(s) of vertical displacement during the current inter-seismic interval. We differentiate the modern patchy distribution of moderate uplift or localized subsidence along the coast to a late stage of elastic strain accumulation during the current inter-seismic interval.

The identification of a late stage of elastic strain accumulation addresses three previously unexplained phenomena in the Cascadia margin, including (1) lack of linear proportionality between the duration of inter-seismic intervals and net 
uplift, (2) apparent intervals of coastal tidal marsh submergence prior to coseismic subsidence, and (3) a negative correspondence between paleo-tsunami runup heights and durations of preceding inter-seismic intervals. The recognition of a late stage of inter-seismic stain accumulation has important implications for hazard mitigation. Firstly, the central Cascadia margin has already accumulated sufficient elastic strain to produce a large magnitude rupture now. Secondly, the tsunami modeling community has misinformed some coastal city officials in falsely diminishing the present tsunami runup threat due to the relatively short period of interseismic strain accumulation ( 300 years since the last Cascadia rupture). Indeed, a near future rupture could yield maximum tsunami runups, relative to the 3000-year record of major paleo-tsunami runup events in the Cascadia margin. Future time-based probability analyses of great earthquake magnitudes and tsunami runup heights need to address the time variable rates of strain accumulation between the three stages of the inter-seismic interval including (1) an early stage of interplate recoupling, (2) a middle stage of interplate coupling and mega-fold development under conditions of convergent elastic strain accumulation, and (3) a late stage of smaller scale vertical displacements but ongoing relatively high rates of convergent elastic strain accumulation.

The relatively high rates of modern horizontal strains in the central Cascadia margin are troubling. These rates, if assumed to be fully elastic, and projected backward for 100 years, could yield an earthquake equivalent in size to the 2011 Japanese earthquake (Mw 9.0 for a $400 \mathrm{~km}$ rupture length). The central Cascadia margin is $800 \mathrm{~km}$ in length. Ruptures of the entire central margin, and/or parts of the north and southern margin would exceed the 9.0 magnitude, as estimated for a $400 \mathrm{~km}$ rupture length of the central Cascadia margin.

It is not known whether potential future short-term changes in GPS measured horizontal strain or vertical displacement will significantly precede the next major rupture of the Cascadia megathrust, though we recommend that the capabilities of the GPS networks in the Pacific Northwest for such monitoring be continued.

\section{References}

[1] Cruikshank, K.M. and Peterson, C.D. (2015) Current State of Strain in the Central Cascadia Margin Derived from Changes in Distance between GPS Stations. Open Journal of Earthquake Research, 4, 23-36.

[2] Peterson, C.D., Cruikshank, K.M. and Darienzo, M. (2012) Coastal Tectonic Strain and Paeloseismicity in the South Central Cascadia Margin, Oregon, USA. In: Vidovic, M., Ed., Earthquakes. Triggers, Environmental Impact and Potential Hazards, NOVA Open Access Publisher, Hauppauge, New York.

[3] PANGA (2016) Pacific Northwest Geodetic Array. http://www.geodesy.cwu.edu/

[4] UNAVCO (2016) University Navstar Consortium. http://www.unavco.org/

[5] Cruikshank, K.M. and Peterson, C.D. (2013) Strain Energy Release from the 2011 9.0 Mw Tōhoku Earthquake, Japan. Open Journal of Earthquake Research, 2, 75-83. https://doi.org/10.4236/ojer.2013.24008 
[6] Goldfinger, C., Kulm, L.D., Yeats, R.S., Mitchell, C.E., Weldon III, R.J., Peterson, C.D., Darienzo, M.E., Grant, W.C. and Priest, G.R. (1992) Neotectonic Map of the Oregon Continental Margin and Adjacent Abyssal Plain, in Open File Report 0-92-4. Oregon Department of Geology and Mineral Industries: Portland, Oregon, 141-144.

[7] Atwater, B.F., Nelson, A.R., Clague, J.J., Carver, G.A., Yamaguchi, D.K., Bobrowsky, P.T., Bourgeois, J., Darienzo, M.E., Grant, W.C., Hemphill-Haley, E., Kelsey, H.M., Jacoby, G.C., Nishenko, S.P., Palmer, S.P., Peterson, C.D. and Reinhart, M.A. (1995) Summary of Coastal Geologic Evidence of Past Great Earthquakes at the Cascadia Subduction Zone. Earthquake Spectra, 11, 1-18. https://doi.org/10.1193/1.1585800

[8] Darienzo, M.E. and Peterson, C.D. (1990) Episodic Tectonic Subsidence of Late Holocene Salt Marshes, Northern Oregon Central Cascadia Margin. Tectonics, 9, 1-22. https://doi.org/10.1029/TC009i001p00001

[9] Atwater, B.F., Musumi-Rokkaku, S., Satake, K., Tsuji, Y., Ueda, K. and Yamaguchi, D.K. (2005) The Orphan Tsunami of 1700. Reston, Virginia. US Geological Survey and University of Washington Press, Seattle, Washington, 133.

[10] Peterson, C.D., Cruikshank, K.M., Darienzo, M.E., Wessen, G., Butler, V. and Sterling, S. (2013) Coseismic Subsidence and Paleotsunami Runup Records from Latest Holocene Deposits in the Waatch Valley, Neah Bay, Northwest Washington, USA: Links to Great Earthquakes in the Northern Cascadia Margin. Journal of Coastal Research, 29, 157-172. https://doi.org/10.2112/JCOASTRES-D-12-00031.1

[11] Peterson, C.D., Carver, G.A., Clague, J.J. and Cruikshank, K.M. (2015) Maximum-Recorded Overland Run-Ups of Major Nearfield Paleotsunamis during the Past 3000 Years along the Cascadia Margin, USA, and Canada. Natural Hazards, 77, 2005-2026. https://doi.org/10.1007/s11069-015-1689-7

[12] Reid, H.F. (1908) The California Earthquake of April 18, 1906: The Mechanics of the Earthquake. Report of the State Earthquake Investigation Commission. Vol. 2. The Carnegie Institution of Washington, Washington DC, 190.

[13] Darienzo, M.E. and Peterson, C.D. (1995) Magnitude and Frequency of Subduction-Zone Earthquakes along the Northern Oregon Coast in the Past 3000 Years. Oregon Geology, 57, 3-12.

[14] Atwater, B.F., Tuttle, M.P., Schweig, E.S., Rubin, C.M., Yamaguchi, D.K. and Hemphill-Halley, I. (2004) Earthquake Recurrence, Inferred from Paleoseismology. In: Gillespie, A.R., Porter, S.C. and Atwater, B.F., Eds., The Quaternary Period in the United States, Elsevier, Amsterdam, 331-350.

[15] Blais-Stevens, A., Rogers, G.C. and Clague, J.J. (2011) A Revised Earthquake Chronology for the last 4000 Years Inferred from Varve-Bounded Debris-Flow Deposits beneath an Inlet near Victoria, British Columbia. Bulletin of the Seismological Society of America, 101, 1-12. https://doi.org/10.1785/0120090360

[16] Peterson, C.D., Clague, J.J., Carver, G.A. and Cruikshank, K.M. (2013) Recurrence Intervals of Major Paleotsuanmis as Calibrated by Historic Tsunami Deposits in Three Localities: Port Alberni, Cannon Beach and Crescent City, along the Cascadia margin, Canada and USA. Natural Hazards, 68, 321-336.

https://doi.org/10.1007/s11069-013-0622-1

[17] Peterson, C.D., Kristensen, K. and Minor, R. (2014) Large-Scale Fluidization Features from Late Holocene Coseismic Paleoliquefaction in the Willamette River Forearc Valley, Central Cascadia Subduction Zone, Oregon, USA. Open Journal of Earthquake Research, 3, 82-99.

[18] Satake, K., Shimazaki, K., Tsuji, Y. and Ueda, K. (1996) Time and Size of Giant Earthquake in Cascadia Inferred from JAPANESE Tsunami Records of January 
1700. Nature, 378, 246-249. https://doi.org/10.1038/379246a0

[19] Peterson, C.D. and Cruikshank, K.M. (2014) Quaternary Tectonic Deformation, Holocene Paleoseismicity, and Modern Strain in the Unusually-Wide Coupled Zone of the Central Cascadia Margin, Washington and Oregon, USA and British Columbia, Canada. Journal of Geography and Geology, 6, 33. https://doi.org/10.5539/jgg.v6n3p1

[20] McNeil, L.C., Goldfinger, C., Yeates, R.S. and Kulm, L.D. (1998) The Effects of Upper plate Deformation on Records of Prehistoric Cascadia Subduction zoNe Earthquakes. In: Stewart, I.S. and Vita-Finzi, C., Eds., Coastal Tectonics, Geological Society of London, London, 321-342.

[21] Geist, E.L. (2005) Local Tsunami Hazards in the Pacific Northwest from Cascadia subduction Zone Earthquakes. In: Kayen, R., Ed., Earthquake Hazards of the Pacific Northwest Coastal and Marine Regions, United States Geological Survey, Reston, 17.

[22] Briggs, G.G. (1994) Coastal Crossing of the Elastic Strain Zero-Isobase, Cascadia Margin, South-Central Oregon Coast. Masters Thesis, Department of Geology, Portland State University, Portland, 251.

[23] Barnett, E.T. (1997) Potential for Coastal Flooding Due to Coseismic Subsidence in the Central Cascadia Margin. Masters Thesis, Department of Geology, Portland State University, Portland, 144.

[24] Fiedorowicz, B.K. (1997) Geologic evidence of historic and preshistoric tsunami inundation at Seaside, Oregon. Masters Thesis, Department of Geology, Portland State University, Portland, 197.

[25] Peterson, C.D. and Scheidegger, K.F. (1982-1984) Unpublished Data.

[26] Malvern, L.E. (1969) Introduction to the Mechanics of Continuous Medium. Prentice-Hall, Inc., Englewood Cliffs, 713.

[27] Wang, K., Hu, Y. and He, J. (2012) Deformation Cycles of Subduction Earthquakes in a Viscoelastic Earth. Nature, 484, 327-332. https://doi.org/10.1038/nature11032

[28] Blewitt, G. and Lavallée, D. (2002) Effect of Annual Signals on Geodetic Velocity. Journal of Geophysical Research, 107. https://doi.org/10.1029/2001JB000570

[29] Rogers, G. and Dragert, H. (2003) Episodic Tremor and Slip on the Cascadia Subduction Zone: The Chatter of Silent Slip. Science, 300, 1942-1943. https://doi.org/10.1126/science.1084783

[30] CORS, (2014) RINEX data files for NOAA CORS Stations. http://geodesy.noaa.gov/CORS/

[31] International GPS Sercice (2014) Final Orbit Ephemeris. http://igscb.jpl.nasa.gov/.

[32] Vermeer, M. and Väisänen, M. (2006) Geodetic Baseline GPS Processing by a Simple Sequential Technique. ION GNSS 19th International Technical Meeting of the Satellite Division. Fort Worth, 2977-2882.

http://www.gpstk.org/pub/Documentation/GPSTkPublications/vermeer-baseline-pr ocessing-ion-gnss-2006.pdf

[33] Tolman, B., Harris, R.B., Gaussiran, T., Munton, D., Little, J., Mach, R., Nelsen, S., Renfro, B. and Schlossberg, D. (2004) The GPS Toolkit-Open Source GPS Software. Proceedings of the 17 th International Technical Meeting of the Satellite Division of the Institute of Navigation (ION GNSS 2004), Long Beach.

[34] R Development Core Team (2008) R: A Language and Environment for Statistical Computing. R Foundation for Statistical Computing. R Foundation for Statistical Computing, Vienna. http://www.R-project.org 
[35] Borre, K. and Strang, G. (2012) Algorithms for Global Positioning. Wellesley Cambridge Press. Cambridge, MA, 433.

[36] Gomberg, J., Bedrosian, P., Bodin, P., Bostock, M., Brudzinski, M., Creager, K., Dragert, H., Egbert, G., Ghosh, A., Henton, J., Houston, H., Kao, H., McCrory, P., Melbourne, T., Peacock, S., Roeloffs, E., Rubinstein, J., Schmidt, D., Trèhu, A., Vidale, J., Wang, K. and Wech, A. (2010) Slow-Slip Phenomena in Cascadia from 2007 and Beyond: A Review. Geological Society of America Bulletin, 122, 963-978. https://doi.org/10.1130/B30287.1

[37] McCaffrey, R., King, R.W., Payne, S.J. and Lancaster, M. (2013) Active Tectonics of Northwestern US inferred from GPS-derived Surface Velocities. Journal of Geophysical Research, 118, 709-723.

[38] Parsons, T., Blakely, R.J., Brocher, T.M., Christensen, N.I., Fisher, M.A., Flueh, E., Kilbride, F., Luetgert, J.H., Miller, K., ten Brink, U.S., Trehu, A.M. and Wells, R.E. (2005) Crustal Structure of the Cascadia Fore Arc of Washington. In: Kayen, R., Ed., Earthquake Hazards of the Pacific Northwest Coastal and Marine Regions, United States Geological Survey, Reston, 40.

[39] Fisher, M.A., Hyndman, R.D., Johnson, S.Y., Brocher, T.M., Crosson, R.S., Wells, R.E., Calvert, A.J. and ten Brink, U.S. (2005) Crustal Structure and Earthquake Hazards of the Subduction Zone in Southwest British Columbia and Western Washington, In: Kayen, C.R., Ed., Earthquake Hazards of the Pacific Northwest Costal and Marine Regions, US Geological Survey, Reston, 23.

http://pubs.usgs.gov/pp/pp1661c/pp1661c.pdf

[40] Goldfinger, C., Grijalva, K., Bürgmann, R., Morey, A.E., Johnson, J.E., Nelson, C.H., Gutiérrez-Pastor, J., Ericsson, A., Karabanov, E., Chaytor, J.D., Patton, J. and Gràcia, E. (2008) Late Holocene Rupture of the Northern San Andreas Fault and Possible Stress Linkage to the Cascadia Subduction Zone. Bulletin of the Seismological Society of America, 98, 861-889. https://doi.org/10.1785/0120060411

[41] Atwater, B.F. (1987) Evidence for Great Holocene Earthquakes along the Outer Coast of Washington State (USA). Science, 236, 942-944.

https://doi.org/10.1126/science.236.4804.942

[42] Burgette, R.J., Weldon II, R.J. and Schmidt, D.A. (2009) Interseismic Uplift Rates for Western Oregon and Along-Strike Variation in Locking on the Cascadia Subduction Zone. Journal of Geophysical Research, 114, 24.

https://doi.org/10.1029/2008jb005679 


\section{Appendix-Data Tables}

Table A1. Results for the new and extended EW baselines. This data updates and extends that presented in [1]. The location of the transects is shown in Figure 2.

\begin{tabular}{|c|c|c|c|c|c|c|c|c|c|c|c|c|}
\hline $\begin{array}{l}\text { From } \\
\text { Station }\end{array}$ & $\begin{array}{c}\text { To } \\
\text { Station }\end{array}$ & Latitude & Longitude & Start Date & End Date & $\begin{array}{l}\text { Num } \\
\text { Points }\end{array}$ & Direction & $d l$ & 1 & Strain & $\begin{array}{c}t \\
\text { value }\end{array}$ & Significant \\
\hline \multicolumn{13}{|c|}{ Vancouver Island Baselines } \\
\hline bcov & eliz & 50.5442420 & -126.8424360 & $1 / 1 / 2008$ & $3 / 31 / 2016$ & 5963 & -165 & -0.0063 & $77,292.9455$ & $-8.13 \times 10^{-8}$ & -46.06 & Yes \\
\hline ntka & quad & 49.5923260 & -126.6165100 & $1 / 1 / 2008$ & $3 / 31 / 2016$ & 5963 & 57 & 0.0114 & $110,249.3835$ & $1.04 \times 10^{-7}$ & 22.78 & Yes \\
\hline ptal & uclu & 49.2561950 & -124.8606970 & $1 / 1 / 2008$ & $3 / 31 / 2016$ & 5953 & -127 & 0.0000 & $61,840.1894$ & $-3.21 \times 10^{-15}$ & -3.71 & Yes \\
\hline ptal & wslr & 49.2561950 & -124.8606970 & $1 / 1 / 2008$ & $3 / 31 / 2016$ & 5797 & 56 & 0.0000 & $170,168.7370$ & $6.19 \times 10^{-16}$ & 3.57 & Yes \\
\hline bamf & nano & 48.8353360 & -125.1348970 & $1 / 1 / 2008$ & $3 / 25 / 2016$ & 5889 & 57 & -0.0050 & $92,102.6511$ & $-5.39 \times 10^{-8}$ & -20.15 & Yes \\
\hline nano & wslr & 49.2947010 & -124.0862740 & $1 / 1 / 2008$ & $3 / 25 / 2016$ & 5730 & 43 & -0.0083 & $124,993.1290$ & $-6.64 \times 10^{-8}$ & -43.49 & Yes \\
\hline clrs & $\mathrm{sc} 04$ & 48.8202130 & -124.1307170 & $1 / 1 / 2008$ & $3 / 31 / 2016$ & 6715 & 70 & 0.0000 & $33,330.6820$ & $8.02 \times 10^{-16}$ & 1.33 & No \\
\hline clrs & ptrf & 48.8202130 & -124.1307170 & $1 / 1 / 2008$ & $3 / 31 / 2016$ & 5901 & -146 & 0.0000 & $37,071.8469$ & $-2.55 \times 10^{-15}$ & -2.71 & Yes \\
\hline neah & ptrf & 48.2977270 & -124.6245760 & $1 / 1 / 2008$ & $3 / 31 / 2016$ & 5748 & 30 & -0.0548 & $175,000.7323$ & $-3.13 \times 10^{-7}$ & -2.55 & Yes \\
\hline gldr & ntka & 49.6814819 & -126.1273131 & $4 / 22 / 2009$ & $3 / 31 / 2016$ & 4889 & -106 & -0.0028 & $36,706.3126$ & $-7.51 \times 10^{-8}$ & -28.46 & Yes \\
\hline gldr & quad & 49.6814819 & -126.1273131 & $4 / 22 / 2009$ & $3 / 31 / 2016$ & 4889 & 49 & -0.0047 & $76,102.5821$ & $-6.12 \times 10^{-8}$ & -15.45 & Yes \\
\hline \multicolumn{13}{|c|}{ Northern Olympic Transect } \\
\hline neah & $\mathrm{p} 403$ & 48.2977270 & -124.6245760 & $1 / 7 / 2006$ & $3 / 31 / 2016$ & 4549 & 126 & 0.0003 & $44,517.3471$ & $7.73 \times 10^{-9}$ & 3.17 & Yes \\
\hline $\mathrm{p} 403$ & $\mathrm{p} 435$ & 48.0619860 & -124.1404210 & $4 / 13 / 2007$ & $1 / 18 / 2011$ & 1871 & 91 & -0.0050 & $47,527.3362$ & $-1.05 \times 10^{-7}$ & -11.34 & Yes \\
\hline $\mathrm{p} 435$ & $\mathrm{p} 436$ & 48.0595010 & -123.5030430 & $4 / 13 / 2007$ & $7 / 26 / 2015$ & 2668 & 93 & 0.0007 & $27,550.2545$ & $2.37 \times 10^{-8}$ & 5.28 & Yes \\
\hline blyn & $\mathrm{chcm}$ & 48.0158260 & -122.9273800 & $5 / 5 / 2007$ & $12 / 3 / 2013$ & 1704 & 93 & 0.0304 & $11,348.0046$ & $2.68 \times 10^{-6}$ & 15.31 & Yes \\
\hline blyn & $\mathrm{p} 436$ & 48.0158260 & -122.9273800 & $4 / 13 / 2007$ & $9 / 29 / 2013$ & 2004 & -78 & -0.0218 & $15,769.3536$ & $-1.38 \times 10^{-6}$ & -6.68 & Yes \\
\hline $\mathrm{chcm}$ & $\mathrm{p} 437$ & 48.0105420 & -122.7756750 & $10 / 14 / 2008$ & $7 / 26 / 2015$ & 1020 & 92 & -0.1019 & $23,652.5177$ & $-4.31 \times 10^{-6}$ & -23.09 & Yes \\
\hline $\mathrm{p} 437$ & weez & 48.0017310 & -122.4589990 & $10 / 14 / 2008$ & $8 / 5 / 2010$ & 598 & 98 & -0.0026 & $19,192.0564$ & $-1.34 \times 10^{-7}$ & -2.70 & Yes \\
\hline lkcp & weez & 47.9443420 & -121.8306780 & $10 / 11 / 2008$ & $8 / 5 / 2010$ & 1586 & -83 & -0.0112 & $28,155.3026$ & $-3.99 \times 10^{-7}$ & -8.29 & Yes \\
\hline lkcp & qmar & 47.9443420 & -121.8306780 & $12 / 20 / 2007$ & $7 / 26 / 2015$ & 7529 & 107 & 0.0483 & $67,434.6435$ & $7.17 \times 10^{-7}$ & 14.48 & Yes \\
\hline chel & qmar & 47.8314360 & -119.9897190 & $1 / 1 / 2010$ & $6 / 30 / 2016$ & 1075 & -95 & 0.4238 & $73,361.7659$ & $5.78 \times 10^{-6}$ & 13.06 & Yes \\
\hline chel & lkcp & 47.8314360 & -119.9897190 & $1 / 1 / 2010$ & $7 / 16 / 2015$ & 738 & -85 & -1.0842 & $138,246.8515$ & $-7.84 \times 10^{-6}$ & -17.36 & Yes \\
\hline chel & $\mathrm{p} 453$ & 47.8314360 & -119.9897190 & $1 / 1 / 2010$ & $6 / 30 / 2016$ & 1075 & 95 & -0.0782 & $93,585.9195$ & $-8.35 \times 10^{-7}$ & -1.28 & No \\
\hline dvpt & $\mathrm{p} 453$ & 47.6559440 & -118.1475100 & $1 / 1 / 2009$ & $6 / 30 / 2016$ & 2313 & -76 & 0.0144 & $46,297.7414$ & $3.12 \times 10^{-7}$ & 1.23 & No \\
\hline dvpt & spkn & 47.6559440 & -118.1475100 & $1 / 1 / 2010$ & $6 / 30 / 2016$ & 1277 & 94 & 1.7034 & $48,556.4879$ & $3.51 \times 10^{-5}$ & 26.76 & Yes \\
\hline spkn & inw1 & 47.6279570 & -117.5021140 & $1 / 1 / 2010$ & $2 / 12 / 2011$ & 280 & 78 & 4.2592 & $44,090.3013$ & $9.66 \times 10^{-5}$ & 27.88 & Yes \\
\hline koot & inw1 & 47.7706230 & -116.8094200 & $1 / 1 / 2010$ & $2 / 12 / 2011$ & 288 & -125 & -0.0012 & $10,974.3311$ & $-1.14 \times 10^{-7}$ & -0.11 & No \\
\hline bigd & chel & 47.9331160 & -118.9885440 & $1 / 1 / 2010$ & $6 / 30 / 2016$ & 1086 & -99 & 1.2760 & $75,732.4254$ & $1.68 \times 10^{-5}$ & 94.41 & Yes \\
\hline chel & $\mathrm{p} 454$ & 47.8314360 & -119.9897190 & $1 / 1 / 2010$ & $6 / 30 / 2016$ & 1094 & 80 & -0.4442 & $94,463.2880$ & $-4.70 \times 10^{-6}$ & -5.44 & Yes \\
\hline \multicolumn{13}{|c|}{ Tacoma E-W Transect } \\
\hline enum & pcol & 47.2058120 & -121.9551470 & $5 / 15 / 2007$ & $7 / 26 / 2015$ & 857 & -95 & 0.1129 & $46,781.5885$ & $2.41 \times 10^{-6}$ & 18.89 & Yes \\
\hline p418 & p423 & 47.2363450 & -123.4073760 & $4 / 21 / 2007$ & $7 / 26 / 2015$ & 1175 & 81 & 0.0006 & $35,771.1680$ & $1.58 \times 10^{-8}$ & 3.89 & Yes \\
\hline
\end{tabular}




\section{Continued}

\begin{tabular}{|c|c|c|c|c|c|c|c|c|c|c|c|c|}
\hline $\mathrm{p} 418$ & pabh & 47.2363450 & -123.4073760 & $4 / 21 / 2007$ & $7 / 26 / 2015$ & 1086 & -93 & -0.0052 & $60,402.4794$ & $-8.54 \times 10^{-8}$ & -10.34 & Yes \\
\hline lngb & $\mathrm{p} 423$ & 47.2187860 & -122.7583160 & $4 / 22 / 2005$ & $7 / 26 / 2015$ & 6804 & -61 & -0.0026 & $15,834.2221$ & $-1.64 \times 10^{-7}$ & -40.59 & Yes \\
\hline lngb & pcol & 47.2187860 & -122.7583160 & $9 / 5 / 2013$ & $7 / 26 / 2015$ & 438 & 110 & -0.0104 & $15,129.2994$ & $-6.87 \times 10^{-7}$ & -7.65 & Yes \\
\hline enum & htch & 47.2058120 & -121.9551470 & $9 / 21 / 2008$ & $1 / 19 / 2011$ & 220 & 92 & 0.0379 & $75,010.1278$ & $5.05 \times 10^{-7}$ & 2.04 & Yes \\
\hline cpud & htch & 47.4301070 & -120.3140770 & $1 / 1 / 2010$ & $2 / 12 / 2011$ & 288 & -118 & -0.2108 & $55,962.9731$ & $-3.77 \times 10^{-6}$ & -7.68 & Yes \\
\hline cpud & $\mathrm{p} 452$ & 47.4301070 & -120.3140770 & $1 / 1 / 2010$ & $6 / 30 / 2016$ & 464 & 93 & -0.6247 & $62,472.9933$ & $-1.00 \times 10^{-5}$ & -20.53 & Yes \\
\hline $\mathrm{p} 452$ & sprg & 47.4034790 & -119.4871330 & $1 / 1 / 2010$ & $6 / 30 / 2016$ & 1043 & 96 & & & & & No \\
\hline sprg & ltah & 47.3097530 & -117.9751110 & $1 / 1 / 2010$ & $6 / 30 / 2016$ & 1221 & 93 & 0.2129 & $61,455.7538$ & $3.46 \times 10^{-6}$ & 35.95 & Yes \\
\hline \multicolumn{13}{|c|}{ Olympic E-W Transect } \\
\hline $\mathrm{p} 430$ & tumw & 47.0035450 & -123.4358230 & $5 / 14 / 2007$ & $7 / 26 / 2015$ & 3301 & 93 & 0.0023 & $39,939.6333$ & $5.73 \times 10^{-8}$ & 8.46 & Yes \\
\hline $\mathrm{p} 430$ & twhl & 47.0035450 & -123.4358230 & $4 / 12 / 2005$ & $6 / 18 / 2015$ & 4603 & 88 & -0.0040 & $39,117.6621$ & $-1.02 \times 10^{-7}$ & -6.63 & Yes \\
\hline cpxf & muir & 46.8400000 & -122.2565180 & $6 / 9 / 2008$ & $7 / 25 / 2015$ & 2718 & 91 & & & & & No \\
\hline cpxf & mrsd & 46.8400000 & -122.2565180 & $6 / 14 / 2008$ & $7 / 25 / 2015$ & 2782 & 99 & -0.0354 & $39,764.0035$ & $-8.90 \times 10^{-7}$ & -1.28 & No \\
\hline muir & p065 & 46.8354930 & -121.7329330 & $6 / 9 / 2008$ & $7 / 25 / 2015$ & 2613 & 89 & -0.1082 & $61,091.1351$ & $-1.77 \times 10^{-6}$ & -7.25 & Yes \\
\hline mrsd & p065 & 46.7851970 & -121.7417540 & $6 / 14 / 2008$ & $7 / 25 / 2015$ & 2693 & 84 & 0.0091 & $62,099.3006$ & $1.47 \times 10^{-7}$ & 12.54 & Yes \\
\hline p065 & $\mathrm{sc00}$ & 46.8439240 & -120.9326380 & $4 / 14 / 2007$ & $7 / 26 / 2015$ & 3579 & 53 & 0.0129 & $19,847.8839$ & $6.49 \times 10^{-7}$ & 9.43 & Yes \\
\hline $\operatorname{sc00}$ & $\operatorname{linh}$ & 46.9509250 & -120.7246090 & $1 / 1 / 2007$ & $7 / 26 / 2015$ & 4012 & 69 & 0.0005 & $15,207.4010$ & $2.97 \times 10^{-8}$ & 5.49 & Yes \\
\hline \multicolumn{13}{|c|}{ Willapa Bay E-W Transect } \\
\hline $\mathrm{p} 421$ & $\mathrm{p} 431$ & 46.5314880 & -122.4287890 & $5 / 15 / 2007$ & $5 / 31 / 2015$ & 3446 & 83 & -0.0018 & $34,122.7837$ & $-5.34 \times 10^{-8}$ & -25.51 & Yes \\
\hline $\mathrm{p} 417$ & $\mathrm{p} 420$ & 46.5744520 & -123.2975050 & $1 / 5 / 2010$ & $7 / 26 / 2015$ & 3750 & 87 & -0.0029 & $33,222.0447$ & $-8.81 \times 10^{-8}$ & -10.54 & Yes \\
\hline $\mathrm{p} 420$ & $\mathrm{p} 421$ & 46.5886028 & -122.8663310 & $1 / 5 / 2010$ & $7 / 26 / 2015$ & 4422 & 101 & & & & & No \\
\hline $\mathrm{p} 431$ & $\mathrm{p} 432$ & 46.5717410 & -121.9880850 & $1 / 1 / 2010$ & $5 / 31 / 2015$ & 3113 & 76 & -0.0035 & $26,782.5801$ & $-1.31 \times 10^{-7}$ & -1.92 & No \\
\hline $\mathrm{p} 432$ & yaki & 46.6228556 & -121.6832290 & $1 / 1 / 2010$ & $7 / 26 / 2015$ & 4067 & 92 & -0.0030 & $90,274.7981$ & $-3.36 \times 10^{-8}$ & -21.44 & Yes \\
\hline vrnt & yaki & 46.6367140 & -119.7318030 & $1 / 1 / 2010$ & $7 / 10 / 2015$ & 4031 & -94 & -0.0034 & $59,316.3111$ & $-5.80 \times 10^{-8}$ & -28.47 & Yes \\
\hline \multicolumn{13}{|c|}{ Portland E-W Transect } \\
\hline $\mathrm{p} 405$ & $\mathrm{p} 411$ & 45.6291810 & -123.6435610 & $5 / 4 / 2007$ & $7 / 26 / 2015$ & 6374 & 105 & 0.0016 & $39,336.0558$ & $4.12 \times 10^{-8}$ & 12.14 & Yes \\
\hline $\mathrm{p} 411$ & $\mathrm{p} 427$ & 45.5379790 & -123.1571040 & 4/13/2007 & $7 / 26 / 2015$ & 5256 & 101 & -0.0007 & $64,971.4228$ & $-1.06 \times 10^{-8}$ & -4.80 & Yes \\
\hline $\mathrm{p} 427$ & pkdl & 45.4300420 & -122.3404790 & $1 / 23 / 2009$ & $7 / 26 / 2015$ & 3586 & 81 & 0.0001 & $61,540.8547$ & $2.19 \times 10^{-9}$ & 1.32 & No \\
\hline pkdl & tdls & 45.5181860 & -121.5634530 & $1 / 23 / 2009$ & $8 / 15 / 2015$ & 3593 & 74 & -0.0075 & $35,317.6913$ & $-2.12 \times 10^{-7}$ & -85.96 & Yes \\
\hline $\mathrm{p} 445$ & tdls & 45.5899740 & -120.6720680 & $9 / 23 / 2008$ & $7 / 26 / 2015$ & 3768 & -87 & -0.0035 & $35,833.2726$ & $-9.64 \times 10^{-8}$ & -13.19 & Yes \\
\hline $\mathrm{p} 445$ & $\mathrm{p} 447$ & 45.5899740 & -120.6720680 & $10 / 14 / 2008$ & $7 / 26 / 2015$ & 3897 & 102 & 0.0061 & $78,238.6865$ & $7.74 \times 10^{-8}$ & 18.30 & Yes \\
\hline $\operatorname{arln}$ & $\mathrm{p} 445$ & 45.7080840 & -120.1830700 & $9 / 23 / 2008$ & $7 / 26 / 2015$ & 3696 & -109 & -0.0038 & $40,401.5620$ & $-9.32 \times 10^{-8}$ & -54.98 & Yes \\
\hline $\operatorname{arln}$ & $\mathrm{p} 450$ & 45.7080840 & -120.1830700 & $9 / 23 / 2008$ & $1 / 12 / 2015$ & 3327 & 61 & 0.0050 & $57,072.4825$ & $8.69 \times 10^{-8}$ & 5.07 & Yes \\
\hline $\mathrm{p} 450$ & pndl & 45.9531750 & -119.5439850 & $5 / 24 / 2010$ & $3 / 1 / 2011$ & 432 & 119 & 0.0207 & $66,463.5300$ & $3.12 \times 10^{-7}$ & 14.83 & Yes \\
\hline p447 & pndl & 45.4526800 & -119.6899450 & $5 / 24 / 2010$ & $3 / 1 / 2011$ & 432 & 71 & -0.0035 & $74,180.2729$ & $-4.73 \times 10^{-8}$ & -1.41 & No \\
\hline
\end{tabular}




\section{Continued}

\begin{tabular}{|c|c|c|c|c|c|c|c|c|c|c|c|}
\hline \multicolumn{12}{|c|}{ Newport E-W Transect } \\
\hline hlsy & p374 & $44.3776050-123.1086830$ & $4 / 20 / 2007$ & $12 / 3 / 2013$ & 1903 & -89 & -0.0040 & $38,377.3118$ & $-1.03 \times 10^{-7}$ & -17.57 & Yes \\
\hline hlsy & sthm & $44.3776050-123.1086830$ & $12 / 27 / 2006$ & $9 / 29 / 2013$ & 1928 & 86 & -0.0024 & $29,944.5179$ & $-7.95 \times 10^{-8}$ & -13.77 & Yes \\
\hline p383 & sthm & $44.3419990-122.2169000$ & $10 / 22 / 2007$ & 9/29/2013 & 2061 & -82 & -0.0082 & $41,664.0462$ & $-1.96 \times 10^{-7}$ & -12.98 & Yes \\
\hline p383 & p385 & $44.3419990-122.2169000$ & $10 / 23 / 2007$ & $7 / 8 / 2015$ & 421 & 65 & -0.0006 & $23,955.7932$ & $-2.61 \times 10^{-8}$ & -3.31 & Yes \\
\hline p385 & p387 & $44.4348480-121.9458340$ & $8 / 23 / 2007$ & $7 / 26 / 2015$ & 524 & 118 & 0.0011 & $33,348.0252$ & $3.40 \times 10^{-8}$ & 8.13 & Yes \\
\hline p387 & $\mathrm{rmdb}$ & $44.2966300-121.5742880$ & $4 / 13 / 2007$ & $7 / 26 / 2015$ & 3737 & 97 & -0.0040 & $34,307.3942$ & $-1.17 \times 10^{-7}$ & -93.10 & Yes \\
\hline redm & $\mathrm{rmdb}$ & $44.2597667-121.1478810$ & $1 / 22 / 2005$ & $8 / 15 / 2015$ & 4312 & 101 & & & & & No \\
\hline p367 & p374 & $44.5852465-124.0615700$ & $4 / 13 / 2007$ & $7 / 26 / 2015$ & 3699 & 121 & -0.0075 & $43,749.1439$ & $-1.72 \times 10^{-7}$ & -9.63 & Yes \\
\hline \multicolumn{12}{|c|}{ Cape Blanco E-W Transect } \\
\hline ddsn & p369 & $43.1187917-123.2442410$ & $1 / 11 / 2006$ & $7 / 26 / 2015$ & 1176 & -81 & -0.0002 & $15,276.3993$ & $-1.14 \times 10^{-8}$ & -1.21 & No \\
\hline p061 & p364 & $42.9673860-124.0137910$ & $10 / 16 / 2008$ & $7 / 8 / 2015$ & 969 & -67 & -0.0010 & $34,992.6460$ & $-2.74 \times 10^{-8}$ & -4.47 & Yes \\
\hline chem & ddsn & $43.2242320-121.7856240$ & $12 / 21 / 2008$ & $8 / 15 / 2015$ & 922 & -96 & 0.0228 & $119,187.1383$ & $1.91 \times 10^{-7}$ & 19.37 & Yes \\
\hline chem & p062 & $43.2242320-121.7856240$ & $12 / 21 / 2008$ & $7 / 26 / 2015$ & 888 & 103 & 0.0069 & $57,890.5638$ & $1.19 \times 10^{-7}$ & 13.64 & Yes \\
\hline p062 & p381 & $43.1122360-121.0905500$ & $10 / 16 / 2008$ & $7 / 26 / 2015$ & 900 & 98 & 0.0115 & $93,611.9844$ & $1.23 \times 10^{-7}$ & 16.37 & Yes \\
\hline p061 & p369 & $42.9673860-124.0137910$ & $4 / 20 / 2007$ & $7 / 8 / 2015$ & 1047 & 68 & 0.0018 & $51,345.2464$ & $3.59 \times 10^{-8}$ & 5.61 & Yes \\
\hline p381 & p390 & $43.0016180-119.9516460$ & $10 / 16 / 2008$ & $7 / 26 / 2015$ & 908 & 88 & 0.0099 & $83,513.7964$ & $1.19 \times 10^{-7}$ & 15.50 & Yes \\
\hline \multicolumn{12}{|c|}{ Ashland E-W Transect } \\
\hline p179 & p734 & $42.0989420-123.6853670$ & $10 / 31 / 2008$ & $3 / 31 / 2016$ & 92 & -93 & -0.0075 & $50,341.6685$ & $-1.48 \times 10^{-7}$ & -1.75 & No \\
\hline p370 & p380 & $42.1907820-122.6561430$ & $7 / 4 / 2010$ & $7 / 26 / 2015$ & 3682 & 84 & -0.0024 & $72,792.3819$ & $-3.36 \times 10^{-8}$ & -15.42 & Yes \\
\hline $\mathrm{mdmt}$ & p380 & $42.4183417-121.2216010$ & $7 / 4 / 2010$ & $7 / 26 / 2015$ & 3481 & -111 & -0.0006 & $49,266.6980$ & $-1.32 \times 10^{-8}$ & -4.59 & Yes \\
\hline \multicolumn{12}{|c|}{ Crescent City E-W Transect } \\
\hline p154 & ptsg & $41.8070830-123.3600500$ & $1 / 2 / 2010$ & $3 / 25 / 2016$ & 4199 & -92 & -0.0043 & $74,452.3090$ & $-5.81 \times 10^{-8}$ & -31.04 & Yes \\
\hline p154 & p784 & $41.8070830-123.3600500$ & $1 / 2 / 2010$ & $3 / 31 / 2016$ & 4378 & 88 & -0.0021 & $78,118.2927$ & $-2.69 \times 10^{-8}$ & -17.24 & Yes \\
\hline p154 & ybhb & $41.8070830-123.3600500$ & $1 / 2 / 2010$ & $3 / 31 / 2016$ & 4383 & 99 & -0.0015 & $54,646.7908$ & $-2.76 \times 10^{-8}$ & -10.30 & Yes \\
\hline ptsg & p387 & $41.7825350-124.2550260$ & $1 / 2 / 2010$ & $3 / 25 / 2016$ & 4160 & 39 & -0.0219 & $354,511.1109$ & $-6.17 \times 10^{-8}$ & -22.30 & Yes \\
\hline p786 & ptsg & $41.8457000-123.9801000$ & $1 / 2 / 2010$ & $2 / 15 / 2016$ & 4113 & -107 & -0.0078 & $23,842.9414$ & $-3.26 \times 10^{-7}$ & -2.05 & Yes \\
\hline p154 & p786 & $41.8070830-123.3600500$ & $1 / 2 / 2010$ & $2 / 15 / 2016$ & 4290 & -85 & -0.0033 & $51,746.3376$ & $-6.47 \times 10^{-8}$ & -35.60 & Yes \\
\hline p784 & ybhb & $41.8308160-122.4204560$ & $1 / 2 / 2010$ & $3 / 31 / 2016$ & 4381 & -115 & -0.0024 & $26,531.6901$ & $-8.93 \times 10^{-8}$ & -21.10 & Yes \\
\hline p672 & porc & $41.7116000-121.5069000$ & $9 / 24 / 2011$ & $7 / 29 / 2014$ & 238 & 101 & 0.0234 & $64,839.1346$ & $3.61 \times 10^{-7}$ & 6.03 & Yes \\
\hline porc & wrnr & $41.5995000-120.7432000$ & 9/24/2011 & $7 / 29 / 2014$ & 236 & 100 & 0.0113 & $28,622.1398$ & $3.95 \times 10^{-7}$ & 1.78 & No \\
\hline lngv & supr & $41.7852000-119.7524000$ & $8 / 26 / 2011$ & $2 / 5 / 2015$ & 274 & -118 & -0.0474 & $29,702.4152$ & $-1.60 \times 10^{-6}$ & -6.72 & Yes \\
\hline lngv & shld & $41.7852000-119.7524000$ & $8 / 26 / 2011$ & $10 / 5 / 2015$ & 666 & 82 & 0.0004 & $61,908.7275$ & $7.12 \times 10^{-9}$ & 0.12 & No \\
\hline p672 & p784 & $41.7116000-121.5069000$ & $1 / 2 / 2010$ & $3 / 25 / 2016$ & 4138 & -80 & -0.0017 & $77,117.4536$ & $-2.19 \times 10^{-8}$ & -13.97 & Yes \\
\hline \multicolumn{12}{|c|}{ Cape Mendocino E-W Transect } \\
\hline p158 & p160 & $40.4225000-124.1072000$ & $1 / 1 / 2009$ & $3 / 31 / 2016$ & 4442 & -9 & -0.0037 & $14,489.9683$ & $-2.53 \times 10^{-7}$ & -78.43 & Yes \\
\hline p160 & p793 & $40.5513000-124.1333000$ & $4 / 30 / 2009$ & $3 / 25 / 2016$ & 4133 & 100 & -0.0066 & $48,155.8429$ & $-1.36 \times 10^{-7}$ & -82.47 & Yes \\
\hline p332 & p793 & $40.5467000-123.1745000$ & $4 / 30 / 2009$ & $3 / 25 / 2016$ & 4095 & -103 & -0.0024 & $34,618.9983$ & $-6.80 \times 10^{-8}$ & -35.70 & Yes \\
\hline
\end{tabular}




\section{Continued}

\begin{tabular}{lcccccccccccc}
\hline p332 & p341 & 40.5467000 & -123.1745000 & $1 / 1 / 2009$ & $3 / 31 / 2016$ & 4396 & 77 & -0.0024 & $49,417.4060$ & $-4.90 \times 10^{-8}$ & -32.40 & Yes \\
p341 & p349 & 40.6507000 & -122.6069000 & $1 / 1 / 2009$ & $3 / 31 / 2016$ & 4416 & 70 & -0.0017 & $25,896.4010$ & $-6.73 \times 10^{-8}$ & -33.18 & Yes \\
p348 & p349 & 40.9055000 & -121.8280000 & $1 / 1 / 2009$ & $3 / 31 / 2016$ & 4302 & -115 & -0.0012 & $45,784.8402$ & $-2.51 \times 10^{-8}$ & -15.34 & Yes \\
hcro & p348 & 40.8159000 & -121.4699000 & $1 / 1 / 2009$ & $3 / 31 / 2016$ & 4306 & -72 & -0.0015 & $31,804.3640$ & $-4.58 \times 10^{-8}$ & -24.91 & Yes \\
heav & hcro & 40.7828000 & -120.7286000 & $11 / 19 / 2009$ & $4 / 18 / 2014$ & 118 & -87 & -0.0181 & $62,679.4272$ & $-2.89 \times 10^{-7}$ & -3.77 & Yes \\
obsv & rave & 40.7354000 & -120.1575000 & $1 / 18 / 2014$ & $1 / 24 / 2014$ & 14 & -87 & -0.7642 & $18,771.0019$ & $-4.07 \times 10^{-5}$ & -0.21 & No \\
heav & rave & 40.7828000 & -120.7286000 & $1 / 14 / 2012$ & $1 / 23 / 2014$ & 70 & 99 & -0.0363 & $29,822.8603$ & $-1.22 \times 10^{-6}$ & -1.58 & No \\
bflo & obsv & 40.7288000 & -119.8287000 & $9 / 19 / 2015$ & $3 / 31 / 2016$ & 106 & -89 & -0.4817 & $27,788.0314$ & $-1.73 \times 10^{-5}$ & -1.68 & No \\
bflo & p137 & 40.7288000 & -119.8287000 & $7 / 8 / 2009$ & $3 / 31 / 2016$ & 146 & 79 & 0.0438 & $30,264.4815$ & $1.45 \times 10^{-6}$ & 8.53 & Yes \\
blrk & p137 & $40.7697000-119.0933000$ & $11 / 5 / 2011$ & $1 / 6 / 2014$ & 41 & -88 & 0.0603 & $32,400.9835$ & $1.86 \times 10^{-6}$ & 1.10 & No \\
\hline
\end{tabular}

Table A2. Results for the new and extended NS baselines. This data extends that presented in [1].

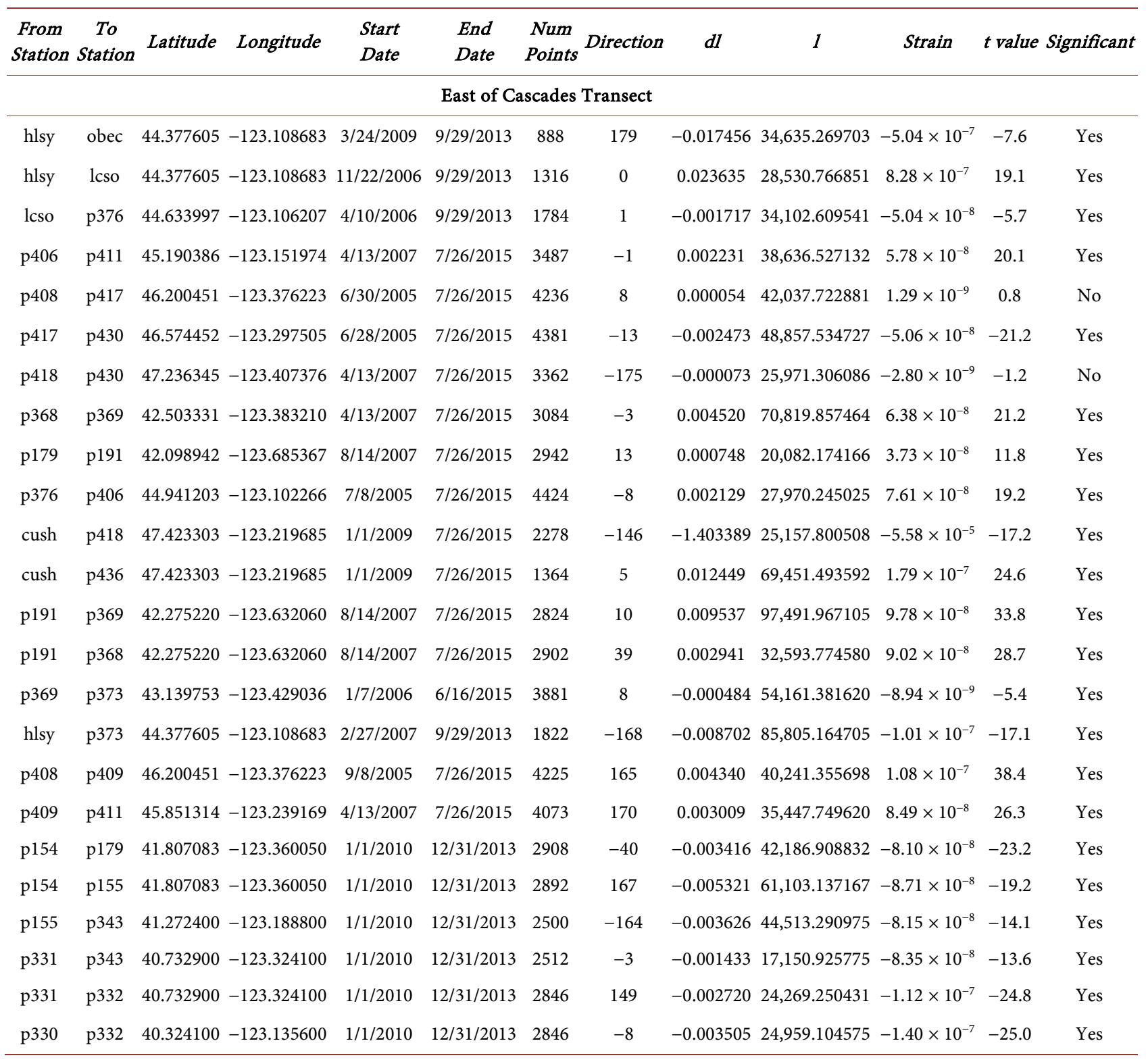




\section{Continued}

\begin{tabular}{|c|c|c|c|c|c|c|c|c|c|c|c|}
\hline \multicolumn{11}{|c|}{ Coast Range Transect } & \multirow[b]{2}{*}{ Yes } \\
\hline p020 & $\mathrm{p} 453$ & $47.002208-118.565770$ & $1 / 1 / 2007$ & $7 / 26 / 2015$ & 6053 & -9 & -0.002518 & $85,247.284330$ & $-2.95 \times 10^{-8}$ & -13.4 & \\
\hline kahl & p020 & $46.641066-118.557222$ & $5 / 11 / 2007$ & $10 / 11 / 2011$ & 3200 & -1 & 0.003173 & $40,147.931110$ & $7.90 \times 10^{-8}$ & 1.7 & No \\
\hline p021 & $\mathrm{p} 453$ & $48.674580-118.730067$ & $1 / 1 / 2007$ & $7 / 26 / 2015$ & 5128 & -179 & -0.002568 & $101,826.055700$ & $-2.52 \times 10^{-8}$ & -15.0 & Yes \\
\hline kahl & pndl & $46.641066-118.557222$ & $5 / 24 / 2010$ & $3 / 1 / 2011$ & 434 & -171 & 0.080378 & $109,499.943100$ & $7.34 \times 10^{-7}$ & 2.2 & Yes \\
\hline pndl & p386 & $45.669631-118.790797$ & $5 / 24 / 2010$ & $3 / 1 / 2011$ & 436 & -174 & -0.011790 & $141,474.358300$ & $-8.33 \times 10^{-8}$ & -1.7 & No \\
\hline ors1 & p386 & $44.164247-119.058800$ & $8 / 14 / 2007$ & $7 / 26 / 2015$ & 4709 & 15 & -0.006238 & $27,493.848940$ & $-2.27 \times 10^{-7}$ & -18.0 & Yes \\
\hline ors1 & p392 & $44.164247-119.058800$ & $8 / 14 / 2007$ & $7 / 26 / 2015$ & 4840 & 177 & 0.001288 & $79,871.055820$ & $1.61 \times 10^{-8}$ & 4.5 & Yes \\
\hline ors2 & p386 & $44.164139-119.058800$ & $8 / 25 / 2007$ & $7 / 26 / 2015$ & 3782 & 15 & -0.006714 & $27,499.058230$ & $-2.44 \times 10^{-7}$ & -15.1 & Yes \\
\hline p390 & p392 & $43.033886-118.928351$ & $10 / 14 / 2008$ & $7 / 26 / 2015$ & 7958 & -7 & -0.000454 & $46,243.089850$ & $-9.81 \times 10^{-9}$ & -4.4 & Yes \\
\hline ors2 & p392 & $44.164139-119.058800$ & $8 / 25 / 2007$ & $7 / 26 / 2015$ & 3942 & 177 & -0.001518 & $79,857.565980$ & $-1.90 \times 10^{-8}$ & -4.0 & Yes \\
\hline $\ln r d$ & shld & $41.476600-118.710100$ & $7 / 1 / 2011$ & $6 / 13 / 2013$ & 288 & -30 & -0.014553 & $50,415.310840$ & $-2.89 \times 10^{-7}$ & -2.1 & Yes \\
\hline $\ln r d$ & sknd & $41.476600-118.710100$ & $7 / 1 / 2011$ & $5 / 17 / 2013$ & 234 & 180 & -0.022861 & $49,430.747750$ & $-4.62 \times 10^{-7}$ & -2.2 & Yes \\
\hline rose & tire & $40.804100-118.712500$ & $1 / 1 / 2010$ & $12 / 28 / 2011$ & 96 & 158 & -0.121327 & $18,817.648370$ & $-6.45 \times 10^{-6}$ & -19.2 & Yes \\
\hline
\end{tabular}

Table A3. Results for the new and extended quadrilateral data (see Figure 2 for locations of quadrilaterals). This data updates and extends that presented in [1].

\begin{tabular}{|c|c|c|c|c|c|c|c|c|c|c|}
\hline $\begin{array}{l}\text { From } \\
\text { Station }\end{array}$ & $\begin{array}{c}\text { To } \\
\text { Station }\end{array}$ & Latitude & Longitude & Start Date & $\begin{array}{l}\text { End } \\
\text { Date }\end{array}$ & Num Points & Direction & Strain & \multicolumn{2}{|c|}{$t$ value Significant } \\
\hline \multicolumn{11}{|c|}{ Northern California Quadrangle } \\
\hline p339 & p344 & 40.034100 & -122.668200 & $1 / 1 / 2008$ & $10 / 17 / 2015$ & 5288 & 102 & $-0.00341555,930.899054-6.11 \times 10^{-8}$ & -51.4 & Yes \\
\hline p336 & p344 & 39.528100 & -122.430500 & $1 / 1 / 2008$ & $3 / 31 / 2016$ & 5924 & 38 & $-0.00327956,335.350101-5.82 \times 10^{-8}$ & -40.7 & Yes \\
\hline p335 & p336 & 39.726200 & -122.873600 & $6 / 13 / 2008$ & $3 / 31 / 2016$ & 5440 & 120 & $-0.00052943,999.345782-1.20 \times 10^{-8}$ & -6.4 & Yes \\
\hline p335 & p339 & 39.726200 & -122.873600 & $6 / 13 / 2008$ & $10 / 17 / 2015$ & 4804 & 27 & $-0.00423938,469.198010-1.10 \times 10^{-8}$ & -50.5 & Yes \\
\hline p335 & p344 & 39.726200 & -122.873600 & $6 / 13 / 2008$ & $3 / 31 / 2016$ & 5440 & 73 & $-0.00388875,865.106799-5.12 \times 10^{-8}$ & -35.9 & Yes \\
\hline p336 & p339 & 39.528100 & -122.430500 & $1 / 1 / 2008$ & $10 / 17 / 2015$ & 5288 & -20 & $-0.00519759,772.517588-8.69 \times 10^{-8}$ & -53.6 & Yes \\
\hline \multicolumn{11}{|c|}{ Olympic Quadrangle } \\
\hline $\mathrm{p} 401$ & $\mathrm{p} 402$ & 47.937050 & -124.556820 & $1 / 1 / 2008$ & $11 / 15 / 2011$ & 2822 & 135 & $-0.00347526,731.265988-1.30 \times 10^{-7}$ & -50.3 & Yes \\
\hline $\mathrm{p} 401$ & $\mathrm{p} 403$ & 47.937050 & -124.556820 & $1 / 1 / 2008$ & $11 / 15 / 2011$ & 2764 & 66 & $-0.00794334,031.164555-2.33 \times 10^{-7}$ & -24.3 & Yes \\
\hline $\mathrm{p} 402$ & $\mathrm{sc} 03$ & 47.766113 & -124.305714 & $1 / 1 / 2008$ & $11 / 15 / 2011$ & 2778 & 83 & $-0.00403145,365.495642-8.89 \times 10^{-8}$ & -14.8 & Yes \\
\hline $\mathrm{p} 403$ & $\mathrm{sc} 03$ & 48.061986 & -124.140421 & $1 / 1 / 2008$ & $11 / 15 / 2011$ & 2720 & 130 & $-0.00772942,509.902266-1.82 \times 10^{-7}$ & -14.6 & Yes \\
\hline $\mathrm{p} 401$ & $\mathrm{sc} 03$ & 47.937050 & -124.556820 & $1 / 1 / 2008$ & $12 / 3 / 2013$ & 3445 & 102 & $0.001334 \quad 65,114.528597 \quad 2.05 \times 10^{-8}$ & 2.7 & Yes \\
\hline $\mathrm{p} 402$ & $\mathrm{p} 403$ & 47.766113 & -124.305714 & $1 / 1 / 2008$ & $11 / 15 / 2011$ & 2749 & 21 & $-0.00524635,159.695802-1.49 \times 10^{-7}$ & -37.7 & Yes \\
\hline neah & $\mathrm{p} 403$ & 48.297727 & -124.624576 & $1 / 7 / 2006$ & $11 / 15 / 2011$ & 4549 & 126 & $0.00034444,517.347117 \quad 7.73 \times 10^{-9}$ & 3.2 & Yes \\
\hline neah & $\mathrm{p} 401$ & 48.297727 & -124.624576 & $1 / 1 / 2008$ & $12 / 3 / 2013$ & 3423 & 173 & $-0.00398140,424.468086-9.85 \times 10^{-8}$ & -33.3 & Yes \\
\hline \multicolumn{11}{|c|}{ SE Oregon (Burns Junction) Quadrangle } \\
\hline p390 & p392 & 43.033886 & -118.928351 & $10 / 14 / 2008$ & $7 / 26 / 2015$ & 7958 & -7 & $-0.00045446,243.089846-9.81 \times 10^{-9}$ & -4.4 & Yes \\
\hline p392 & p393 & 43.446599 & -119.000837 & $10 / 14 / 2008$ & $10 / 31 / 2013$ & 3485 & 105 & $-0.00605992,982.354934-6.52 \times 10^{-8}$ & -29.6 & Yes \\
\hline
\end{tabular}




\section{Continued}

\begin{tabular}{|c|c|c|c|c|c|c|c|c|c|c|c|}
\hline burn & p392 & $42.779500-117.843529$ & $8 / 14 / 2007$ & $7 / 26 / 2015$ & 4646 & -52 & 0.002749 & $119,895.360158$ & $2.29 \times 10^{-8}$ & 7.5 & Yes \\
\hline burn & p390 & $42.779500-117.843529$ & $10 / 14 / 2008$ & $7 / 26 / 2015$ & 3805 & -73 & 0.002058 & $93,022.922122$ & $2.21 \times 10^{-8}$ & 7.6 & Yes \\
\hline burn & p393 & $42.779500-117.843529$ & $10 / 14 / 2008$ & $10 / 31 / 2013$ & 3404 & -4 & -0.004888 & $50,710.530964$ & $-9.64 \times 10^{-8}$ & -31.2 & Yes \\
\hline p390 & p393 & $43.033886-118.928351$ & $10 / 14 / 2008$ & $10 / 31 / 2013$ & 3466 & 76 & -0.004234 & $87,239.021448$ & $-4.85 \times 10^{-8}$ & -26.5 & Yes \\
\hline \multicolumn{12}{|c|}{ Vernonia Quadrangle } \\
\hline p405 & p407 & $45.629181-123.643561$ & $5 / 4 / 2007$ & $7 / 26 / 2015$ & 2347 & -32 & -0.000494 & $42,514.295553$ & $-1.16 \times 10^{-8}$ & -3.8 & Yes \\
\hline p407 & p408 & $45.954651-123.930828$ & $4 / 13 / 2007$ & $7 / 26 / 2015$ & 3273 & 58 & -0.001433 & $50,853.212199$ & $-2.82 \times 10^{-8}$ & -7.0 & Yes \\
\hline p407 & p409 & $45.954651-123.930828$ & $4 / 13 / 2007$ & $7 / 26 / 2015$ & 3380 & 102 & 0.002081 & $54,878.092183$ & $3.79 \times 10^{-8}$ & 10.2 & Yes \\
\hline p408 & p409 & $46.200451-123.376223$ & $9 / 8 / 2005$ & $7 / 26 / 2015$ & 4225 & 165 & 0.004340 & $40,241.355698$ & $1.08 \times 10^{-7}$ & 38.4 & Yes \\
\hline p405 & p409 & $45.629181-123.643561$ & $5 / 4 / 2007$ & $7 / 26 / 2015$ & 2479 & 52 & 0.004123 & $39,992.976944$ & $1.03 \times 10^{-7}$ & 19.5 & Yes \\
\hline p405 & $\mathrm{p} 411$ & $45.629181-123.643561$ & $5 / 4 / 2007$ & $7 / 26 / 2015$ & 6374 & 105 & 0.001620 & $39,336.055845$ & $4.12 \times 10^{-8}$ & 12.1 & Yes \\
\hline p409 & p411 & $45.851314-123.239169$ & $4 / 13 / 2007$ & $7 / 26 / 2015$ & 4073 & 170 & 0.003009 & $35,447.749620$ & $8.49 \times 10^{-8}$ & 26.3 & Yes \\
\hline p409 & $\mathrm{p} 414$ & $45.851314-123.239169$ & $1 / 31 / 2008$ & $7 / 26 / 2015$ & 975 & 93 & -0.001068 & $42,503.618734$ & $-2.51 \times 10^{-8}$ & -5.4 & Yes \\
\hline p411 & p414 & $45.537979-123.157104$ & $1 / 31 / 2008$ & $7 / 26 / 2015$ & 981 & 48 & 0.002912 & $48,974.955184$ & $5.95 \times 10^{-8}$ & 8.4 & Yes \\
\hline p408 & $\mathrm{p} 446$ & $46.200451-123.376223$ & $4 / 9 / 2008$ & $7 / 26 / 2015$ & 2712 & 104 & 0.001834 & $38,541.187943$ & $4.76 \times 10^{-8}$ & 2.9 & Yes \\
\hline p409 & p446 & $45.851314-123.239169$ & $4 / 9 / 2008$ & $7 / 26 / 2015$ & 2782 & 43 & -0.002315 & $39,814.452101$ & $-5.82 \times 10^{-8}$ & -8.1 & Yes \\
\hline p414 & p446 & $45.834868-122.692838$ & $5 / 13 / 2008$ & $7 / 26 / 2015$ & 881 & -26 & -0.000509 & $34,846.944770$ & $-1.46 \times 10^{-8}$ & -1.2 & No \\
\hline
\end{tabular}

Submit or recommend next manuscript to SCIRP and we will provide best service for you:

Accepting pre-submission inquiries through Email, Facebook, LinkedIn, Twitter, etc. A wide selection of journals (inclusive of 9 subjects, more than 200 journals)

Providing 24-hour high-quality service

User-friendly online submission system

Fair and swift peer-review system

Efficient typesetting and proofreading procedure

Display of the result of downloads and visits, as well as the number of cited articles

Maximum dissemination of your research work

Submit your manuscript at: http://papersubmission.scirp.org/

Or contact ojer@scirp.org 